\section{The Arabic}

\section{Commentary on}

\section{the Golden Verses}

\section{Attributed to}

\section{Proclus, and Its}

Neoplatonic

\section{Context}

\section{ANNA IZDEBSKA}

Max Planck Institute for the History of Science

Berlin, Germany

Institute for Religious Studies

Jagiellonian University in Krakow

Poland

mitzner.izdebska@gmail.com

\section{ABSTRACT}

The modern edition of the Arabic commentary to a Greek Pythagorean poem known as the Golden Verses, attributed to Proclus, was first published in 1984, more than a quarter century ago. Despite the fact that this Graeco-Arabic text is an interesting example of a late antique Neoplatonic philosophical commentary and it offers a Neoplatonic interpretation of various elements of the Pythagorean tradition, it has hardly been studied as such at all. In this article I argue that there exist enough arguments to conclude that this text contains a number of genuine Neoplatonic elements and should be studied along with the other late antique texts from this tradition. Moreover, I demonstrate that in all probability this text actually comes from the inner circle of Proclus Diadochus' students, or from the philosopher himself. 
The Arabic commentary to the Golden Verses $^{1}$ that is attributed to Proclus has been classified by Concetta Luna and Alain-Philippe Segonds, the authors of the entry about Proclus in the

It is a philosophical poem (71 verses) in hexameter, and attributed to Pythagoras or generally seen as originating in the circle of the first Pythagoreans. In fact it was probably composed in the Hellenistic or Early Roman period. It consists of admonitions from a teacher (Pythagoras) to his students, mainly about the proper philosophical way of life, with some elements of metaphysics and theology. It became very popular as a source of Pythagorean wisdom in the Late Roman period and was treated as a classical Pythagorean text by late antique authors such as lamblichus (who commented on the last verses of the poem in his Protrepticus) and Hierocles (who wrote the commentary to this poem which is fully preserved). Thom 1995; van der Horst 1932.
Dictionnaire des philosophes antiques, as the last item on a list of "falsely attributed writings" ("ouvrages faussement attribués") of Proclus. ${ }^{2}$ According to them, the "attribution of this text to Proclus, which without doubt utilises a Greek and Neoplatonic model, is very controversial", and "there is nothing specifically Proclean in the text that could support its attribution to Proclus Diadochus". ${ }^{3}$

Obviously, a text that has been labelled as an Arabic translation of something "falsely attributed" to Proclus does not sound particularly attractive

2 Luna \& Segonds 2012, pp. 1652-53.

3 This entry is followed in turn by an entry devoted to Proclus' writings preserved in Arabic where both the Arabic commentary to the Golden Verses and the discussion about its authorship are briefly summarised. Endress 2012, pp. 1673-74. 
or worthy of study. Unsurprisingly, despite the fact this text is an interesting example of a late antique Neoplatonic philosophical commentary and it offers a Neoplatonic interpretation of various elements of the Pythagorean tradition, it has hardly been studied as such at all. ${ }^{4}$ In this paper, therefore, I will argue that there exist enough arguments to conclude that this text contains a number of genuine Neoplatonic elements and should be studied along with the other late antique texts from this tradition. Moreover, I will demonstrate that in all probability this text actually comes from the inner circle of Proclus Diadochus' students, or from the philosopher himself.

\section{PROCLUS DIADOCHUS OF LYCIA OR PROCLUS PROCLEIUS OF LAODICEA?}

The commentary is preserved in a single manuscript, Escorial Arab. 888, which contains a collection of various texts and summaries translated from Greek and Syriac into Arabic, entitled Kitāb an-nukat wa-ț-timār at-țibbīya wa-l-falsafīya (Book of Medical and Philosophical Gifts and Fruits) (it is the 14th of the 18 sections, on fols. 91a-114a). ${ }^{5}$ The author of this collection is Abū-l-Farağ Abdallāh Ibn al-Ṭayyib (d. AD 1043),

4 Although this avenue of research has been suggested by the current author in her earlier work: Izdebska 2011; Izdebska 2016.

5 An incomplete list of the contents of this manuscript is available in Brockelmann 1943-49, I 635, and Brockelmann 1937-42, I 884. More on this manuscript: Daiber 1995 , p. 630, n. 8; Wakelnig 2013, p. 39 n. 108; Ferrari 2006, p. 28. a Syriac bishop and church official, philosopher, physician and theologian. Ibn al-Tayyib was a prolific author of biblical commentaries, but he also commented on a huge amount of works of Aristotle, Galen and Hippocrates. ${ }^{6}$ The most famous and influential of those works were his commentaries on Porphyry's Isagoge and Aristotle's Categories. ${ }^{7} \mathrm{His}$ knowledge of Greek philosophy was profound, which is visible in the manuscript Escorial Arab. 888, which contains his collection of translations, summaries and abridgements of various Greek and Arabic works.

The text that is the object of this study is also presented as an abridgement made by Ibn al-Tayyib. The exact title at the beginning of the text is: The essentials of the treatise of Pythagoras known as the Golden Proclus' commentary (Istithmār muqāla fithāghūras ma'arūfa bi-l-dhahabiya tafsīr bruqlus). The provenance of this extract (thamarat) from the commentary of Proclus is again emphasised at the very end of the text. Istithmār means literally "extracting the fruit" and thamarat "a fruit". According to F. Rosenthal, it was Ibn al-Tayyib's “favourite word for the numerous brief summaries of the contents of Greek works prepared by him". ${ }^{8}$ Rosenthal compared another istithmār from this manuscript, an excerpt from the Arabic synopsis of Plato's Laws, with the same text preserved elsewhere and attributed to al-Fārābī, and he concluded that "it is

Faultless 2010, p. 668.

Gyekye 1975; Gyekye 1979; Ferrari 2006. Rosenthal 1990, p. 274. 
a true abridgement, often using the same words" 9 and "using the abridgement of the Laws as the basis of judgment, it can be said that Ibn al-Tayyib's work as an abbreviator was quite skilful, if thoroughly prosaic and uninspired". ${ }^{10}$

The text was edited and translated into English by N. Linley, ${ }^{11}$ who unfortunately died tragically before finishing his edition and only expressed his initial thoughts about the authorship of this text in a short introduction. He rejected $^{12} \mathrm{R}$. Walzer's hypothesis ${ }^{13}$ that it could have been a summary based on the preserved Commentary on the Golden Verses of Hierocles (Walzer based his hypothesis on the fact that the names Proclus and Hierocles look almost the same in Arabic). The two texts have almost nothing in common, so this hypothesis can indeed be easily rejected. However, Linley was still sceptical about the Proclean authorship of the text that served as the basis for Ibn al-Ṭayib's summary: "there is no positive ground to support the view that Ibn

9 Rosenthal 1990, p. 276. The fact that Ibn al-Tayyib was a scrutinous translator and compilator was also pointed out by Daiber in his review of Linley's edition of the Commentary (1988, p. 135). However, E. Wakelnig remarked that this manuscript containing Ibn al-Tayyib's collection "has not been properly studied yet" (Wakelnig 2013, p. 39).

10 Rosenthal 1990, pp. 276-77. Also H. Daiber in his review of the Linley's edition of the Commentary points out the fact that Ibn al-Tayyib was a scrutinous translator and compilator (Daiber 1988, p. 135).

11 Linley 1984.

12 Linley 1984, p. vi.

13 R. Walzer, Encyclopaedia of Islam, I (New Edition, Leiden, 1960), s.v. Buruklus.
al-Tayyib had access to a commentary by

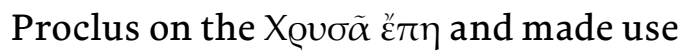
of it as a basis for his own work." ${ }^{14}$

In the Arabic tradition the existence of a commentary to the Golden Verses attributed to Proclus which Ibn al-Tayyib would have read and abbreviated is attested by a famous scholar and bibliographer Ibn al-Nadīm (10th c.) in his Catalogue (Fihrist, 264, ed. G. Flügel). He listed it among other works of Proclus Diadochus:

Commentary on the Golden testaments of Pythagoras - it is about one hundred leaves and extant in Syriac. He wrote it for his daughter. Thabit translated three of its leaves, but [then] died, so that he did not complete it. (p. 608, tr. B. Dodge, The Fihrist of al-Nadìm: A Tenth-Century Survey of Islamic Culture, vol. 2, New York 1970)

Therefore, there probably existed a Greek text of a commentary to the Golden Verses attributed to Proclus that was already translated into Syriac in the times of Ibn al-Nadìm. It was this text that Ibn al-Tayyib abbreviated from a Greek, Syriac or Arabic version. The information that Proclus wrote it for his daughter is suspicious since we know that he had neither a wife nor any children. ${ }^{15}$

The other trace of the existence of this text and of its translation into Arabic is a fragment of it that survives

14 Linley 1984, $x$.

15 Marinus, Proclus (17); Damascius, Philosophical history / Life of Isidore 56 (ed. Athanassiadi, p. 159). 
in the manuscript Oxford Marsh 539, edited and translated by E. Wakelnig as Philosophy Reader from the Circle of Miskawayh (passage \# 16, pp. 74-75). As. E. Wakelnig remarked: "Passage 16 of the Philosophy Reader is strikingly parallel to Ibn al-Tayyib's Istithmar in content, but completely different in wording. The simplest explanation for this parallel is to assume a common source for both texts, namely an Arabic translation of Proclus' commentary."16 The striking differences in wording between this passage and the version by Ibn al-Tayyib indicate that there existed an Arabic translation of the commentary independent from Ibn al-Tayyib's summary; in other words, they are not the same text. However, given the fact that the differences are so substantial and that according to F. Rosenthal Ibn al-Tayyib was usually quite straight in his abridgements, it is also possible that he abbreviated a Syriac or Greek version or had a different Arabic translation at his disposal. In summary, we can conclude that the text that we have in Ibn al-Tayyib's abridgement certainly existed in Greek and reached the Arabic world through various channels of transmission. Moreover, Ibn al-Nadīm and Ibn al-Tayyib were both convinced that the original text was written by Proclus Diadochus.

The reason why the mider scholarship has problems with attributing this text to Proclus Diadochus is the fact that there is now no surviving evidence for a commentary on the Golden Verses authored by this Neoplatonic philosopher in the Greek texts. This is why the majority of modern scholars follow the idea of L. G. Westerink, who in the most extensive paper about the authorship of this text ever published suggested that its author was not Proclus Diadochus, but Proclus Procleius of Laodicea. ${ }^{17}$

This other Proclus is known from two sources, and no work that he would have authored survives in the Greek corpus, even in fragments. Our knowledge of his writings comes only from the 10th-century Byzantine lexicon-encyclopaedia known as the Souda (Pi, 2472):

Proclus, the one surnamed Prokleios; son of Themesion, of Laodikeia in Syria, a hierophant. He wrote a Theology, On the Myth of Pandora in Hesiod, On the Golden Verses, On the Introduction to Arithmetic of Nicomachus; and some other geometrical works. ${ }^{18}$

As I have already mentioned, none of the writings listed by the author of this entry are preserved in Greek and their existence is not attested by any other Greek author. However, Damascius in the Commentary to Plato's Philebus (19) mentions Proclus of Laodicea in the context of the cult of Hedone as a deity. As he says, this cult "is testified by Proclus of Laodicea". ${ }^{19}$

\footnotetext{
17 Westerink 1987a.

18 "Proclus." Suda On Line. Tr. Ronald Allen. 1 August 2008. Accessed 7 August 2007 <http://www.stoa.org/sol-entries/ $\mathrm{pi} / 2472>$.

19 Westerink 2010, pp. 12-14; Damascius 2008, pp. 7-8. See also Westerink 1987a, p. 75. According to Westerink, Damascius'
} 
Given this paucity of sources, we should actually ask if this other Proclus really existed, or - rather - if he produced the works that the Souda lists for him. ${ }^{20}$ From among the titles that the Souda attributes to him, only the commentary to the myth of Pandora is a distinctive title and the rest is very general. The Theology could somehow reflect the Proclean Platonic theology or the Elements of theology. The Nicomachean Introduction to arithmetic was very popular among the late antique Neoplatonists and many of them wrote a commentary to this text, with Iamblichus being the most famous among them and his commentary the only one that is preserved. ${ }^{21}$ Neither is the Commentary to the Golden Verses an unusual title: there survives such a commentary written by Hierocles of Alexandria, and the poem was also commented by Iamblichus in his Protrepticus (but only verses 45-71).

mention of Proclus of Laodicea in the context of this cult informs us that his alleged lost Theology was rather about cult and not about theology per se.

In fact, Westerink also described one more possible reference to the name of this Proclus in Greek literature, in the commentary to Aristotle of PseudoAlexander (CAG II 3, 8.28-9.1). The author refers to Proclus as the author of the work entitled List of feasts. However, Westerink himself qualified this passage as a very improbable mention of Proclus of Laodicea, because the manuscripts do not even allow us to decide if the name mentioned is Proclus or Patrocles. There is also no mention of Laodicea. Therefore I will not use this reference as an argument in favour of the existence of Proclus Procleius. See Westerink 1987a, pp. 75-76.

21 Robbins, D'Ooge \& Karpinski 1926, pp. 124-132.
There is also one more extant Arabic commentary to this Pythagorean poem, which is attributed to Iamblichus. ${ }^{22}$ Nicomachus' Introduction as well as the Golden Verses belonged to the Neoplatonic teaching curriculum in Late Antiquity and such titles in a dossier of an alleged Neoplatonic author would be an obvious element. Some other writings concerning geometry could have also been connected with Proclus, such as the Commentary to Euclid, and they are also something we would expect in a late antique Neoplatonic philosopher's dossier.

As I have already mentioned, the only distinctive title is the commentary to Hesiod's myth of Pandora. However, there is a commentary to Hesiod's Works and Days attributed to Proclus in which the myth of Pandora is also described. ${ }^{23}$ Thus, again, as with the Theology, it could have been a work "inspired" by a work of the "real" Proclus that was added by mistake. We do not know if Proclus Diadochus wrote commentaries to Nicomachus and the Golden Verses, but they were so popular among the other Neoplatonists that it is very plausible that he himself also wrote such commentaries or some of his students wrote them down from his lectures and later attributed them to him. In fact, a hypothesis (that is nonetheless rejected by L. G. Westerink) that Proclus wrote a commentary to the Nicomachus' Introduction has also been made and, in

Daiber 1995.

This text is now considered to be based on an earlier commentary of Plutarch that was slightly reworked by Proclus. See Faraggiana di Sarzana 1987. 
this case, the Souda entry about Proclus of Laodicea would actually provide evidence for that - assuming that the author of this entry or its source mistook the two Procluses. ${ }^{24}$ To sum up, there is nothing in the Souda that could not be a vague mention of the works authored by Proclus Diadochus himself.

Despite this fact, L. G. Westerink defends the actual existence of Proclus Procleius as the author of the writings listed in the Souda. ${ }^{25} \mathrm{He}$ rejects the possibility that this list could derive from the known works of Proclus Diadochus, an idea already suggested by L. J. Rosán. ${ }^{26}$ According to Westerink, in the case of each of the pairs of writings (of Proclus Diadochus and Proclus of Laodicea) the obvious correspondence is "not complete nor exact". ${ }^{27}$ However, it is still astonishing that these works are, in the end, astonishingly similar, even if they cannot be easily identified as being one and the same. Moreover, the fact that we have no writings by the other Proclus at all, and almost no other information about him and his works, should actually cast doubt on the testimony of the late Byzantine lexicon.

Another important fact is that the list of works of this otherwise unknown Proclus of Laodicea is so stereotypical and unspecific that it can easily be connected not only with a list of the works of Proclus Diadochus, but with any other late Neoplatonic author. This makes

24 See the summary of this discussion in Luna \& Segonds 2012, pp. 1641-1642.

25 Westerink 1987a, p. 74.

26 Rosan 1949, p. 11, n. 1.

27 Westerink 1987a, pp. 74-75. the entire entry preserved in the Souda even more suspicious. Such a list could have easily been made up on the basis of the author's knowledge about a usual Neoplatonic dossier and in particular about the dossier of Proclus Diadochus himself. In fact, there is a possibility that the author of this biographical note knew the name of Proclus of Laodicea, the hierophant from Damascius' commentary, and within the scope of some early medieval project of collecting all the possible information about all Greek philosophers and scientists he "invented" his plausible list of writings. ${ }^{28}$

28 The author of this note was probably one of the earlier authors of late antique and Byzantine Onomatologoi (Tables of Eminent Writers), which were used by the author/authors of the Souda for the compiling of the lexicon. The most famous of such works was the Onomatologos by Hesychius of Miletus (5th-6th c. AD), who is mentioned as an important source in the Souda itself ("of which the present book is an epitome"; however, this is probably not a statement about the Souda itself, but about some epitome that was at its author(s) disposal). In fact, Hesychios' Onomatologos became so famous in Byzantium that many other, later Onomatologoi were also attributed to him. By the 19th century there was already a lively debate on the extent to which Hesychius' work was the source for the Souda. The most prevalent opinion nowadays is that the Souda was based on a broader collection of such sources. Moreover, it is possible that Hesychius' Onomatologos covered only the authors of the classical period and all later material comes from other sources. A. Adler, the editor of the Souda (Suidae Lexicon, Leipzig 1928-1935) tried to identify a possible source for every entry and she attributed the entry about Proclus Procleius to Hesychius himself. This attribution was later accepted and repeated by L. G. Westerink (p. 74) and more recently by E. Wakelnig (p. 38). However, 
E. Wakelnig, who edited and translated the manuscript Oxford Marsh 539, in which the Arabic commentary attributed to Proclus is quoted, addressed the question of the authorship of the commentary in her introduction. ${ }^{29}$ She argued in favour of Westerink's hypothesis about Proclus Procleius, pointing to the "hitherto rather puzzling fact that Ibn Buṭlān, according to Yāqūt, claims that Proclus was from Latakia, the ancient Laodicea. This claim must surely refer to Proclus Procleius, who is said to have been from Laodicea in Syria (Souda, Pi, 2472) and has thus left his trace in Arabic." 30 As she adds in the note, Yāqūt "further calls Proclus the author of the Arguments for the Eternity of the World, which may indicate confusion on the part of either Ibn Buṭlān or a later transmitter or Yāqūt who wanted to display his familiarity with Proclus and thus added this mismatched reference to the Arguments." 31 However, this argument should possibly be inverted. Ibn Buṭlān (and the same statement was also repeated, quoting him, by al-Qifti ${ }^{32}$ ), a later transmitter, or Yāqūt, might have known about only

there is no evidence that it was he who was the source of this entry, especially given the fact that this alleged Proclus Procleius would have probably been almost contemporaneous with Hesychius. See the summary of the discussion about Hesychius' Onomatologos as the possible source of Souda in: Kaldellis 2005, esp. pp. 384-389; Wilson, 1983, pp. 145-147; Dickey 2007, pp. 90-91.

29 Wakelnig 2013, pp. 38-39.

30 Wakelnig 2013, p. 38.

31 Wakelnig 2013, p. 38, n. 105.

32 Endress 1973, p. 14. one Proclus (i.e., Proclus Diadochus) and might have simply been convinced that Proclus Diadochus was from Laodicea, and not from Lycia. Prior to Wakelnig, G. Endress actually suggested that Ibn Buṭlān might have simply mistaken Lycia with Latakia (Laodicea). ${ }^{33}$

This hypothesis is even more probable given the fact that the Arabic authors were not aware of where Proclus was born. One can find such names for his home town as Ațātāriya (Fihrist, 252.13), Ațātūla (al-Qifti, 89.3), aț-Ṭarațūsī (in the manuscripts containing the Arabic translation of Proclus' On the Eternity of the World). ${ }^{34}$ Thus, Arabic authors were probably not aware of Proclus' home town of Xanthos in Lycia (and in fact Proclus was actually born in Constantinople, which his parents were visiting at the time of his birth, to only later return to Xanthos, where Proclus spent his childhood). ${ }^{35}$ Furthermore, Arabic authors (or at least most of them) were probably not aware of what Lycia was, since this name of a Roman province ceased to play an important role in Byzantine administrative usage after the 9 th century ${ }^{36}$ and it was probably unknown to Arabic geographers. ${ }^{37}$ Moreover, the Arabic version of the names

33 Endress 1973, p. 14.

34 Endress 1973, pp. 13-14.

35 Marinus, Life of Proclus 6.

36 Hellenkemper \& Hild 2004, pp. 79 and 120.

37 None of the following knows Lycia, while they do know the names of some other "ancient" provinces and the medieval geography of Byzantine Anatolia: Khurradādhbih 1889; Ja'far 1889; Bosworth 1970; Ibn al-Fakîh al-Hamadânî, "Description of the Land of the Byzantines", in Brooks 1901; Ibn Hawqal 
Latakia (Lādhaqiya) and Lycia (Līqīya) look very similar in the Arabic script and one might have been changed into the other by any author or scribe in the process of transmission. Therefore, it would have been easy for them to identify Laodicea as the place of origin of Proclus Diadochus, who was probably the only Proclus they knew of. The connection might have been reinforced by the fact that some other late Neoplatonic philosophers also came from Laodicea, and thus this city might have anyway been known as having a Neoplatonic episode in its history. ${ }^{38}$

L. G. Westerink concludes his analyses with three alternative hypotheses: (1) the commentary is a summary of a lost work of Proclus Diadochus; (2) it is a summary of a lost work by Proclus Procleius; (3) it is a summary of a work by another Neoplatonic author. He then states that he regards the second hypothesis as being corroborated by the information in the Souda. ${ }^{39}$ Still, in the same paper Westerink himself showed many ideas that the Arabic commentary shares with the preserved works of Proclus Diadochus, or the works of other significant Neoplatonic authors. Therefore, it actually looks as if Westerink

1964. I would like to thank Professor John Haldon for his help with these references.

Damascius, in the Philosophical history, writes about "Domninus, the philosopher, was of Syrian stock from Laodicea and Larissa in Syria, a pupil of Syrianus and the fellow-student of Proclus" (Damascius 1999, 89a, translation by P. Athanassiadi on p. 223). He also mentions another Neoplatonist, Maras, from Laodicea (90d).

Westerink 1987a, p. 78. decided that one dubious testimony in the Souda is more convincing than the Arabic tradition contemporary with the Byzantine lexicon (and in fact the Arabic tradition probably had better access to the Greek sources at that time, either in the Greek original or in various translations). Moreover, because of the testimony of the Souda, Westerink dismissed the arguments based on the text's contents, which I discuss and expand on below. Yet, even if Proclus Procleius really existed and even if he actually wrote a commentary to the Golden Verses, this does not mean that he is the author of the Greek text that survives in the Arabic translation. The Golden Verses were very popular among the late antique Neoplatonic philosophers and in all probability commentaries to this text were written not only by Hierocles and Iamblichus, but also by other philosophers, among whom could well have been both Proclus Procleius and Proclus Diadochus. ${ }^{40}$

40 Westerink's hypothesis about the authorship of Proclus Procleius was repeated with even greater confidence by: Luna \& Segonds 2012, pp. 1652-1653; Wakelnig 2013, pp. 38-39; Zampaki 2017. More cautious, but in principle accepting of Westerink's hypothesis were: O'Meara 1989, pp. 231-232; Thom 1995, pp. 23-25; Endress 2012. In this context, however, it is worth emphasising that $\mathrm{H}$. Daiber in his review of Linley's edition criticised Linley as being too cautious in his opinion about the authorship of the text. He pointed at the most obvious analogies with both the Greek works of Proclus and with the Greek tradition in general and the Pythagorean tradition in particular. These include: elements of Pythagoras' biography, the organisation of the first Pythagorean community, the idea of tetractys and number symbolism, the ascetic flavour of the text, the belief that 
THE INTELLECTUAL HORIZONS OF THE COMMENTATOR

The preserved Arabic text is an abridgement of what was probably already a Syriac or Arabic translation of the Greek text. This means there was a whole chain of translators, transmitters and authors who could have changed the original text. However, it is not clear which elements of the text that survived should be qualified as later changes and which derive directly from the Greek original. For example, in Westerink's opinion, the monotheist character of the text, as well as its author's opinion that Empedocles was the author of the Golden Verses, were both later changes. ${ }^{41}$ In fact, both ideas might have been shared by a late Neoplatonic Greek author; moreover, both have significant analogies with the writings of Proclus himself (I address these questions later on).

Given the fact that this version is so heavily reworked, consisting of excerpts that possibly underwent some changes,

Empedocles was a Pythagorean, among others. Daiber also referred to the evidence of Ibn al-Nadim and brought out the context in which the text of the commentary is transmitted (the manuscript of Ibn al-Tayyib). Daiber was thus quite strongly convinced about the Greek and Neoplatonic character of this text and did not see any reason to doubt that it was in fact Proclus Diadochus who wrote it originally ("Inhaltliche Kriterien sprechen nicht gegen eine Zuschreibung dieses Kommentars an Proclus" [p. 137]. Nonetheless, Daiber was not aware of the existence of Westerink's paper about the authorship of the Commentary, nor of Westerink's arguments and the hypothesis of Proclus Procleius. See Daiber 1988. it is striking that it still has the form of a consistent narrative. It is a text that can easily be read as a coherent whole rather than as a mere collection of excerpts from a lost text. However, only some of the verses of the poem are included in and commented on within this narrative, which suggests that it is indeed an abridgement of the original work. Still, it is conceivable that even this selective character of the commentary was the intention of its author from the very beginning. Most of the verses are not quoted, but paraphrased and summarised. In addition, the commentary very often goes quite far into digressions, treating the poem as just a pretext to express the author's own philosophical ideas. Nonetheless, it has to be emphasised that as far as its structure is concerned, this commentary differs a lot from the Greek commentary to the Golden Verses of Hierocles of Alexandria ${ }^{42}$ and from another Arabic commentary to the Golden Verses attributed to Iamblichus. ${ }^{43}$ Both comment on subsequent lemmata from the poem and quote them in their entirety.

The text begins with a short biography of Pythagoras. It is said that he was from Samos, that his birth was predicted by a prophecy and that he was said to have been born of a virgin. The topos of Pythagoras' birth of a virgin can be traced back to the biographies of Pythagoras that started to be composed from around the 1st century BC. They were presenting him as a holy man

42 Köhler 1974. 
and a pagan saint. Elements pointing at the miraculous circumstances of Pythagoras' birth are also present in the preserved late antique biographies of Porphyry (Vita Pyth., 2), Iamblichus (Vita Pythag. II), ${ }^{44}$ and Diogenes Laertius (VIII 1, 4, who follows Heraclides of Pontus; Pythagoras is said to have been claiming that Hermes was his father). ${ }^{45}$ The author of our Arabic commentary is fully aware of the discussions that concerned Pythagoras' divine origins. For instance, later on in the commentary he writes that "there were people who were convinced that Pythagoras was a god, while others regarded him as a mortal" (107a). ${ }^{46}$

Then, it is said that Pythagoras kept company with Thales and travelled to Egypt, a fact mentioned in the biographies by Porphyry (Vita Pyth. 6-12) and Iamblichus (Vita Pythag. II-IV). It is also mentioned that masses of people from all countries were coming to him for healing and that he performed miracles - again, this is part of the image of Pythagoras depicted as a pagan saint, in particular in the late antique biographies.

After this short biographical section, the commentator presents the first Pythagorean community in a way which

44 According to lamblichus, the name of Pythagoras' mother was at first Parthenis ("virgin") and then it was later changed by her husband Mnesarchus into Pythais (after Pythia from the Delphic oracle). He also refers to the stories about Apollo as the real father of Pythagoras.

45 Cf. Westerink 1987a, pp. 62-63; Daiber 1988, pp. 135-136.

$46 \quad$ Linley 1984, pp. 76-77. is also very close to the image of the Pythagorean community presented by Iamblichus in On the Pythagorean way of life:

He used to command his pupils to maintain silence for five years, whereupon he would teach them some philosophy and mathematics. During this period, they would curb their appetites, improve themselves spiritually, and undergo training in ethical conduct. These philosophers kept silence so as to allow their intellects to revert to their essential nature, and to prevent their discourse with themselves from reaching outsiders, and, should they hold converse with an outsider, they would have to purify themselves in the manner appropriate for one who had become polluted by having his intellect won over to something alien. $(91 a-b)^{47}$

This five-year period of silence in the Pythagorean student community was well known and described by many authors. ${ }^{48}$ This is yet another argument showing that the commentator was very well aware of the late antique legend about the first Pythagorean community. ${ }^{49}$ Another example of the acquaintance of the author of the commentary with at least the Iamblichean vision of the first Pythagorean community can be found in two places in the text:

\footnotetext{
$47 \quad$ Linley 1984, pp. 4-5.

48 Hippolytus, Ref. haer. I 2, 16; Plutarch, De curiositate 519c 6-7; Clement of Alexandria, Strom. V 11, 67, 3; Porphyry, Vita Pyth. 19; Iamblichus, Vita Pythag. XVII $72,5$.

49 Cf. Westerink 1987a, p. 63; Daiber 1988, p. 136.
} 
The Pythagoreans used to employ melancholy music to subdue these appetites; they did this particularly when it was time for sleep, so as to ensure that there remained in the imagination no impressions which might disturb their sleep. $(98 b)^{50}$

For the period of sleep, they would employ music such as would purge the soul of malignant fantasies, and they would think about what they had done during the day. (106b)

Those passages are similar to the chapter of the Pythagorean way of life that discusses Pythagoras' ideas about music and the ways in which he used it to influence the souls of his students:

For he corrected each of these [emotions] by the rule of virtue, attempering them through appropriate melodies, as through certain salutary medicines. In the evening, likewise, when his disciples were retiring to sleep, he liberated them by these means from diurnal perturbations and tumults and purified their intellective power from the influxive and effluxive waves of a corporeal nature; rendered their sleep quiet, and their dreams pleasing and prophetic. (XV, trans. T. Taylor) ${ }^{51}$

Altogether, the number of the analogies between the Iamblichean Life and our Arabic commentary is astonishing (I discuss the rest of them in more detail in the final section of this paper). It

50 Linley 1984, pp. 40-41.

51 Taylor 1965, p. 32. shows that the author of the commentary inherited the Iamblichean image of Pythagoras and his vision of the first Pythagorean community. It is very probable that Iamblichus was his main source of knowledge about the early Pythagoreanism and about the figure of Pythagoras.

The affinity of our commentary with the Neoplatonic tradition is also visible in the fact that the words in which our author describes the scope of the poem are very similar to how the Golden Verses were seen by the other Neoplatonic philosophers. The commentary summarises the poem in the following way:

The object of the Golden Sayings is to inspire souls with longing for their perfection and purity, to make people human, and to guide them towards a proper way of life; man achieves perfection by means of absolute virtue, certain knowledge, and virtuous conduct. Some maintain that the Golden Sayings act as a guide towards divine life, the imitation of God and liberation from matter. (91b) ${ }^{52}$

This represents a typical Neoplatonic reading of the poem shared also by Iamblichus (Protr. 40,7-8) and Hierocles of Alexandria (Comm. Aur. carm., 11-6,1). This reading not only focuses on the ethical meaning of the poem and its role as a guide to the philosophical way of life, but also underlines the idea of divination, imitation of God and immortality. It was the reason why the late antique Neoplatonists made the Golden

52 Linley 1984, p. 7. 
Verses an element of their teaching curriculum and used it as a propaedeutic work. Hierocles presents it as such in the introduction to his commentary, and Iamblichus comments on the poem in the most propaedeutic of his texts, the Protrepticus - which can be translated as "Exhortation to philosophy". ${ }^{33}$ The Platonic idea of "becoming like God" (homoiosis theo) that here seems to be the main goal of the Golden Verses was also well known to Proclus, developed by him and incorporated into his own philosophical system. ${ }^{54}$

Another strongly Neoplatonic aspect of the commentary is its religiosity, which very much resembles the late antique pagan religiosity of the philosophers. It is actually the first question on which the author comments (after the biographical introduction about Pythagoras), as it occurs in the very first verses of the poem:

The first of the Golden Exhortations is the reminder that "among the immortals, the first to be honoured according to the statutes of the law is God", for God is the cause of all that exists and the source of all the good things that are present in Totality. $(92 a)^{55}$

In this quotation, the commentator paraphrases the first verse of the poem: "Honour the immortal gods first, in the order appointed by custom." ${ }^{56}$ What the commentator quotes is already modified

53 Cf. Izdebska 2016, pp. 45-50.

54 Berg 2003; Baltzly 2004.

55 Linley 1984, p. 9.

56 Thom 1995, p. 95. so as to fit with his monotheistic ideas. Interestingly, the very same verses are quoted by Proclus Diadochus himself in the Commentary on Timaeus (vol. 1, 203, 25-26, ed. Diehl), but in that case the original version is given. In our case, in theory the change could have been made in the process of the transmission of the text itself, perhaps even by Ibn al-Tayyib or by a translator. However, this seems improbable, as these "monotheistic" verses are then followed by an extensive commentary which addresses the very question of One God who is above the hierarchy of gods. Therefore, if the verses were modified in the process of transmission, they were modified so as to fit the commentary itself. Furthermore, the idea of the one, highest God above the hierarchy of other gods was familiar to the late antique Neoplatonists, including Proclus. ${ }^{57}$ In fact, this particular kind of monotheism - the theory of a transcendent One-God above the entire hierarchy of intellectual and divine beings - represents the core of Proclus' philosophy and it was not at all in conflict with the belief in an entire hierarchy of regular "pagan" gods, subordinated to the Highest one. ${ }^{58}$

However, despite being monotheist, the commentary has a clearly pagan character and elements of the pagan Greek religion, theology and cult play an important role in it, exactly as they did in the work and life of Proclus himself. They are relatively numerous and detailed, which is interesting given that Nuffelen 2010; Mitchell \& Nuffelen 2010; Athanassiadi and Frede 1999.

58

Chlup 2012, pp. 47-62; 112-136. 
the text we have in fact passed through the hands of a Christian intermediary. It is striking that he decided to leave all those elements of the Greek pagan cult in the text, elements that in his time and his cultural and religious context were completely anachronistic, strange, foreign and antiquated. However, this fact may actually serve as a yet another proof that the text of the commentary did not undergo substantial modifications, either by Ibn al-Tayyib or by a translator. This means that the surviving Arabic summary can serve as a reliable approximation of the contents of the Greek original.

The late antique monotheism is not the only recognisable element of the commentator's pagan religiosity. A discussion of the hierarchy of divine and semi-divine beings (God, gods, demons, and heroes) appears as well at the beginning of the commentary, since, again, the beginning of the Golden Verses recommends honouring them. ${ }^{59}$ God is presented as the "Master and Supreme Being", underneath are gods and demons that are "similar to gods and serve them", but "they do not descend into human life"; they are "near to being united with God and are accordingly greatly glorified because of their closeness to God and are held in honour, and have sacrifices offered to them". Heroes, in turn, "are souls which have passed lives as humans and have remained with humans without becoming polluted, and were causes of their goods. After their departure, they go to the Truth, and are elevated, and glimpse the things that are divine," (94a-b). ${ }^{60}$

This description of the three kinds of divine beings, with the One-God above the entire hierarchy, is quite similar to the theology described in the Platonic Theology (books 2-6). However, in the commentary this theology is presented in an abbreviated form, while in the Platonic theology it is spread into several books. As a consequence, the Greek exposition of Proclus' theology is much more sophisticated and covers much more of the metaphysical and soteriological details.

The most significant difference between Proclus' theology and the theology presented in the Arabic commentary is the lack of the category of angels in the latter. In fact, angels do not occur in the text of the commented poem, which seems to be the reason why the commentator does not mention them at all. However, the author does mention the angels at a different place in the commentary: "The demons are deservedly the witnesses of humankind, since they are close to being the angels who are entrusted with their care," (111b). ${ }^{61}$ Therefore, it is probable that the author's own theology was much more complicated that the one presented in the commentary, but the actual discussion was limited because of the contents of the poem - and perhaps also by the propaedeutic goals of the text (contrary to the Platonic Theology, which was written for more advanced and theologically

60 Linley 1984, pp. 19-21.

61 Linley 1984, p. 95. 
aware readers). What is common is of course the importance of the classes of demons and heroes, as well as the description of heroes as human souls who managed to purify themselves and "separate from mankind". Also, both the author of the Commentary and Proclus in Platonic Theology are very attached to the importance of the cult which should be given to demons and heroes. They both emphasise that people owe them honour and should perform specific ancient religious practices to show this attitude. The commentary speaks even about specific priests for various classes of demons, particular dates of their celebration, etc.

Another important Proclean element connected to religious ideas and raised already by Westerink ${ }^{62}$ is the question of Providence and of the influence of the astral bodies on humans and the scale of their freedom.

The commentator is clear in admitting that the astral bodies have some power over us and that there exists justice that gives good to the virtuous and bad to the evil.

The coming of fate to us is the result of the generated bodies and of freedom, which is to say, of heavenly motions and those of ourselves; we should not therefore become annoyed because these things happen to us, nor should we suppose that they befall us because we have deserved them; instead we should behave rationally, so as to be able to accept the gift of those who gave us life. We must not think, either, that the gods are responsible for injustice, but should believe that sickness and poverty and so on are not divinely premeditated, and be courageous when hardships afflict us, and not give in to them. (...)

The skills, the knowledge of which we have derived from the gods, are of help to us in the hardships that beset us during the course of our lives, for, since we are parts of this Whole, we are affected throughout our lives by its upheavals, although, by virtue of the capacity of thinking which we possess, we are in a position to heal ourselves. $(101 b-102 a)^{63}$

This concept of the combination of divine providence with some sort of influence of the heavenly bodies and with the free will of a reasonable man is in complete agreement with the main argument of the Proclean On Providence:

Truly wise people (...) make the god from whom comes the good for all, the primordial cause of all that happens. After him, they posit as cause the periodic revolution of the world and the appropriate time, in which the events are adjusted and ordered to the whole, whereby there is nothing episodic in the government of the whole. They consider themselves to be a third cause whenever they obtain something after making choices and contribute by their own impulses to the accomplishment of what is to be done. $(34 \text {, trans. C. Steel })^{64}$

63 Linley 1984, pp. 53-55.
64 Proclus 2007, p. 57. 
In Proclus' theology, as well as in the Arabic commentary, a man is shown as a free, powerful force in the world - one that can resist bad fate and respond to the divine powers that are above him. It is the Proclean' solution to the conundrum of connecting fate and providence on the one hand, and free human choice on the other. He had a debate about this with a certain "Theodore, an engineer", for which his On Providence is the evidence (it is a polemical reply to a letter that this Theodore wrote to Proclus). ${ }^{65}$ Proclus refers here explicitly to the idea, described by Plato in the Laws (IV 709 b-c), of the three factors playing roles in human life, which he popularized by using them as an argument in this debate.

According to the commentator, to the extent that we realise our rational, divine abilities, we can escape misfortune and bad happenings. According to Proclus, the faculty of choice between good and bad is something specific to humans (in contrast to animals and divine beings) and it gives man a chance to approach the divine:

For a willed life is in accordance with the good and it makes what depends on us extremely powerful and it is really godlike: thanks to this life of the soul becomes god and governs the whole world, as Plato says. (60, trans. C. Steel) $)^{66}$ Hence the virtuous are said to be free and are indeed free, because their activity depends upon them and is not the

65 See the introduction to Proclus 2007 by Steel, pp. 1-37.

66 Proclus 2007, p. 69 slave of what does not depend on them. $(61, \text { trans. C. Steel })^{67}$

Therefore, it is almost certain that the author of the Arabic commentary made use of the Proclean theory of Providence, because we can find exactly the same answers to the same questions. Of course, it does not prove beyond any doubt that the commentator is Proclus himself.

Finally, an even more significant element connecting this Commentary with the preserved Greek works of Proclus is an anecdote about a Pythagorean woman, Theano:

It is said of Theano that when she was angry with one of her servants, she told the servant "If I were not angry, I would hurt you." $(98 a)^{68}$

This anecdote was attributed to various Greek philosophers, among them to Plato and Archytas (DL III 38, 39) but it is only Proclus who in the Ten doubts concerning Providence (86) attributed it, in exactly the same form, to Theano. ${ }^{69}$ This is a yet another strong link between Proclus' Greek writings and the commentary, which suggests that the author of the Greek text that lies beneath the Arabic summary was well acquainted with the world of Proclean ideas.

More generally, as has been demonstrated by Westerink, the

67 Proclus 2007, p. 70.

68 Linley 1984, p. 39.

69 Westerink 1987a, pp. 69-70; Daiber 1988, p. 135. 
commentator shows profound familiarity with the works of Plato, including: ${ }^{70}$ Alcibiades I (the opinion that the mageia of Zoroaster means the cult of gods); Republic (attributes of God described in the second book of this dialogue; the idea that that if there were no justice, there would also be no injustice [I 351c7-352d1]; four cardinal virtues [book IV]; the mind as the eye of the soul [VII 533d2]; the Laws (the commentator talks about showing respect to parents in very similar words); Philebus (the central idea of this dialogue regarding the bodily pleasures not being real pleasures, but only absence of the opposite of real pleasures - pain); Timaeus (four genera of living creatures: celestial, aerial, aquatic, and terrestrial).

Another purely Platonic element that could be added to Westerink's list is the juxtaposition of the "divine part of the soul" and the "animal part" (theriotes) (in Plato, it plays an important role in the Republic: 589d; 590b; 591b); this division corresponds with the division into the rational and irrational parts of the soul. In fact, the very word therion is not a general world for an animal, but rather refers to a wild animal or even a beast, ${ }^{71}$ and so the use of this particular adjective for the description of the lower part of the soul puts emphasis on its irrational nature. In the Arabic commentary, the lower, irrational part of the soul is very often described with the Arabic adjective bahim $\bar{\imath},{ }^{72}$ which means

71 A Greek-English Lexicon, p. 800.

72 Proclus Arab. 97b; 98b; 99a; 100b. the same as the Greek theriotes: wild, animal, bestial. ${ }^{73}$ The commentary uses this word several times and always in the same context in which the Greek word would have been used. When we add to that the arguments listed by Westerink, there is no doubt that the author of our commentary knew very well the contents of Plato's Republic.

Westerink also lists several ideas that the Arabic commentary shares with the Greek Neoplatonic tradition, such as: the triad of being - living - intellect (already noted by Linley and Daiber ${ }^{74}$ ); the hierarchy of divine and quasi-divine beings (even those elements in the commentary that may seem heterodox at first glance are actually in agreement with Proclus' texts); the question of human free will and the influence of the celestial bodies on his action; four classes of numbers: those associated with the divine, the intellect, the soul, and the physical numbers (cf. Proclus' Commentary on Timaeus II 161,26-28); the division of philosophy (and of the

73 The Hans Wehr Dictionary of Modern Written Arabic (Arabic-English), ed. J. M. Cowan, Urbana, Il. 1994, p. 97.

74 Linley 1984, p. ix; Westerink 1987a, p. 66; Daiber 1988, p. 135. However, this is an analogy not only with the writings of Proclus, but also with the writings of many other philosophers who developed this theory after the times of Plotinus. R. Dodds demonstrates that the triad being - life - intellect played an important role in the theologies of Porphyry, lamblichus, Theodor of Asine, the unknown author of the Commentary to Parmenides and Syrianus (and of course Proclus). In Proclus' Elements of theology the triad occurs in L. 115 (pp. 101-103 Dodds). Dodds 1992; Saffrey \& Westerink 1968, I:I: LXV-LXVI; Chlup 2012, pp. 92-99. 
Golden Verses and its commentary) into practical and theoretical parts; the mind as hieratikos; aether as the abode of the souls after death (although in the Greek works of Proclus aether is rather the place where the souls are being judged, and their ultimate abode); symbolic association of the adjective "golden" in the title of the poem with purity. ${ }^{75}$

To conclude, the intellectual horizons of the author of the Greek commentary that we have in the Arabic summary were defined by the late antique Neoplatonic philosophy, in particular with what we call today the "Neopythagorean" current. He was well acquainted with the writings of Plato, as well as with the literary tradition on Pythagoras and the Pythagoreans that was available to late antique authors. Moreover, the commentator shows very close familiarity with the theology and anthropology of Proclus. This does not necessarily mean that the commentator was Proclus himself, but probably somebody close to the Proclean community.

\section{PROCLUS, EMPEDOCLES, AND THE PYTHAGOREAN TRADITION}

In the context of the Proclean character of the Arabic commentary, there remains one possible problem that needs to be resolved: the surprising identification of Empedocles as the author of the Golden Verses.

At the beginning of the Arabic commentary, the author finishes his short historical sketch on Pythagoras and Pythagoreans by introducing

Westerink 1987a, pp. 66-70.
Empedocles as one of the students of Pythagoras:

Prominent amongst Pythagoras' disciples - who numbered about two hundred and fifty - was Empedocles, the author of the Golden Sayings. Empedocles held that the elements were four and believed that the regimen of philosophy reaches completion when the soul becomes divine, and that when the soul is separated from the body, it travels, bloodless and immortal, into the ether. Empedocles was a rigorous ascetic, and a lover of purity. (91b) $)^{76}$

The beginning of this passage is reminiscent of the famous list of Pythagoreans transmitted at the end of Iamblichus' On Pythagorean Life (with which this short biographical introduction has a lot in common), a list that probably comes from Aristoxenus. ${ }^{77}$ It names 235 Pythagoreans, among whom there is also Empedocles. Diogenes Laertius (VIII 1, 3), in turn, gives the number of three hundred students of Pythagoras, following Antiphon. Therefore, the Arabic text that speaks of "about two hundred and fifty" is very close to the number transmitted in the late antique biographies of Pythagoras and once again shows a strong familiarity with this material.

However, the statement that Empedocles is the author of the Golden

\footnotetext{
76 Linley 1984, pp. 4-7.

77 Rohde 1871-1872, p. 171; Diels 1965, p. 23; Timpanaro-Cardini 1958-1964, III 38ff.; Burkert 1972a, p. 105, n. 40; Zhmud 2012b, pp. 235-244; Huffman 2008a.
} 
Verses is quite unusual and needs to be addressed, in particular in the context of the question of the authorship of the commentary. As I mentioned above, Westerink thought that it could be a later Syriac or Arabic addition to the original Greek text. However, the author of this text seemed to be convinced that Empedocles was a Pythagorean and that he wrote the Golden Verses (he mentions this twice in the text, see $91 \mathrm{~b}$ and 107a), although even more often he refers to the verses of the poem as something that Pythagoras said or commended. However, he could have been convinced that it was a collection of real admonitions of Pythagoras that were written down by his student Empedocles. Furthermore, he also refers twice to the Empedoclean philosophy, which he considers the appropriate context for a proper interpretation of the contents of the poem (109a; 110b). The figure of Empedocles and his philosophy, as well as its role in the understanding of the Pythagorean philosophy, seems to be important for the commentator and it would be difficult to remove Empedocles from the text and treat it simply as a later addition, as Westerink suggested. As Daiber observed, the fact that the commentator connected Empedocles with Pythagoreanism is rooted in the Greek tradition and may serve as another argument in favour of the Greek origin of this text. ${ }^{78}$

Indeed, the alleged connection between Empedocles and the Pythagorean tradition is very well attested both in
Greek and in Arabic texts. ${ }^{79}$ Several Greek authors believed that Empedocles was a Pythagorean or at least was closely connected with Pythagoreanism. ${ }^{80}$ Olympiodorus calls him Pythagorean every time he evokes him in his Commentary on Gorgias. ${ }^{81}$ The author of the Theologoumena arithmeticae (Theolog. arithm. p. 22), wrongly attributed to Iamblichus, identified Empedocles as the author of the so-called Pythagorean oath, which is included into the Golden Verses (as v. 47-8): "Yes, by him who imparted to our soul the tetractys, the fount of ever-flowing nature." 82

Oliver Primavesi pointed to the Empedoclean elements in the Pythagorean oath, namely the use of the words pege for "source" and rhidzomata for "elements" (these words occur in another version of the oath, but they are omitted in the Golden Verses). ${ }^{83}$ Furthermore, this is not the only link between Empedocles and the Golden Verses. Another is the word katharmoi

For the Arabic tradition see: S. M. Stern, "Anbaduklīs", in El², vol. I, Leiden 1954, pp. 483-484; De Smet 1998, p. 123.

80 Diog. Laert. VIII 2, 54-55; Sextus Emp., Math. IX 127; Hippol., Haer. VI 26, 3; cf. Proclus, In Parm. 723, 22. See also Burkert 1972, p. 220, n. 12; Kingsley 1995, p. 112; Huffman 1999, pp. 66-87; 75-78; Primavesi 2016.

81 Olympiodorus, In Gorg., intr. 930, 5, 1; $35,12,3$.

82 Thom 1995, p. 97.

83 Primavesi 2016, pp. 14-15. At the same time, he stressed that the word "nature" (physis) is post-Empedoclean and that it leads to the conclusion that the oath, which was widely quoted outside of the context of the poem, was influenced by Empedoclean ideas, but not by Empedocles himself. 
("purifications") in verse 67, which according to Johan $\mathrm{C}$. Thom may be the title of a work to which the poem refers, and we know that there existed a poem of Empedocles whose title was exactly the same. ${ }^{84}$ However, it was certainly not understood as a title of a separate text by the author of the Arabic commentary. Moreover, there are even more striking similarities between the last verses of the poem ("Then, if you leave the body behind and go to the free aither you will be immortal, an undying god, no longer mortal." ${ }^{85}$ ) and a sentence attributed to Empedocles, who according to Clement of Alexandria (Stromata VI 30; frg. 112, v. 4) dared to describe himself as "an immortal god, no longer mortal" (theos ambrotos ouketi thnetos). Although this formula is probably Orphic, ${ }^{86}$ according to Thom, the author of the poem was quoting it as a sentence attributed to Empedocles and as such it may be proof of the post-Empedoclean authorship of the poem itself. ${ }^{87}$

Given these common places and similarities between the Empedoclean heritage and the Golden Verses, and the fact that Empedocles himself wrote poems, it is not surprising that someone in Late Antiquity considered Empedocles to be the author of the Golden Verses. In the description of Empedocles found

84 Thom 1995, p. 216.

85 Thom 1995, p. 99.

86 Thom 1995, pp. 226-229; van der Horst 1932, p. 72.

87 This fragment of Empedocles is considered to be the source for the inclusion of these verses in the Golden Verses, which would be later than the fragment. See Thom 1995, pp. 226-229. in the Arabic text that I already mentioned, someone is clearly making allusions to this topos of "being immortal in the aether" which is Empedocles' own statement, and at the same time is also present in the Golden Verses. It is entirely possible that this analogy led the author of the commentary to the conclusion that it must have been Empedocles himself who wrote the poem. He also described him as a "rigorous ascetic" and a "lover of purity". These statements might allude to the Empedoclean poem Katharmoi (Purifications), and to the presence of the word "purifications" in the Golden Verses.

Of course, it remains to be investigated whether it is at all plausible that Proclus Diadochus or some of his students were convinced about the Empedoclean authorship of the Golden Verses. The Commentary on Plato's Timaeus, the most Pythagorean of the all the preserved works of Proclus, ${ }^{88}$ is the only text in which he mentions the Golden Verses by its title. He refers to it when he writes about the Pythagorean idea of the tetractys: "the father of the Golden Verses also glorifies the Tetrad calling it 'the fountain of ever-flowing Nature'." 89 It is interesting that he did not mention Pythagoras here, so it is not clear whom he meant by "the father of the Golden Verses". One sentence earlier he also quoted another Pythagorean poem,

"But one should also bear in mind that the dialogue is Pythagorean, and one should make one's interpretative comments in a manner that is appropriate to them." (15, 24-28) Tarrant 2006, p. 110. 
a "hymn to number", and he called it "Pythagorean", but neither did he point at Pythagoras as its actual author (vol. 2, p. 53, ed. Diehl). Earlier in the same commentary, Proclus quoted the first verses of the Golden Verses, introducing them with the words: "it is said among the Pythagoreans" (vol. 1, 203, 25-26, ed. Diehl $)^{90}$. In his Commentary on Plato's Republic, he also quoted the same verse about the tetractys, this time again mentioning the poem as a Pythagoreios logos (vol. 2, p. 69, ed. W. Kroll). Furthermore, in the Commentary on Plato's Timaeus he evoked the poem Hieros logos (Sacred discourse; not to be identified with the Golden Verses ${ }^{91}$ ) twice, this time attributing the poem to Pythagoras himself (vol. 3, p. 161, 5; 168, 14, ed. W. Diehl). Therefore, on the ground of the preserved Proclean works, it is possible to assume that he thought that the Hieros logos was written by Pythagoras himself, but that the Golden Verses, which he considered to be something different, were written by one of the Pythagoreans.

However, does it mean that he could have considered Empedocles to be the author of the Golden Verses? In his commentary to another Platonic dialogue, a dialogue that Proclus also considered

90 Tarrant 2006, p. 303.

91 However, it is not clear what this text was and how it was related to the Golden Verses as they are known to us today. According to A. Delatte, the Hieros logos was an older Pythagorean poem of which fragments were used by someone who compiled the Golden Verses. Delatte 1915, pp. 1-79; Thesleff 1961, pp. 18-19, 107; see also Thesleff 1965, pp. 158-166; Thom 1995, pp. 7-8. strongly Pythagorean (i.e. Parmenides), Proclus recalls Empedocles in the context of the Parmenidean discussion about the unity and plurality, and the "divine number":

This is what Empedocles saw later, being a Pythagorean himself, when he called the whole intelligible reality a sphere and says that it converges upon itself by virtue of the goddess of love who beautifies and unifies. For, as he says, all things, in their love and desire for one another, are unified with one another for eternity; and their love is an intelligible love, and their communion and mingling are ineffable. But the mass of men have deserted unity and the monad of things; and their own intrinsically divided and unorganized life carries them down into plurality, to opinions of all sorts, to vague fancies, to feelings and sensations, to physical desires. (Commentary on Plato's Parmenides 723, 22 , trans. G. R. Morrow, J. M. Dillon) ${ }^{92}$

Beyond doubt, here Proclus portrays Empedocles and his teaching as Pythagorean, placing emphasis on his idea of love as the unifying force in the world and recognising in the idea of Empedocles the Pythagorean concept of one versus plurality. Although the fact that Empedocles is here considered a Pythagorean has also been noticed by Westerink, ${ }^{93}$ he did not connect this locus with the Arabic commentary to the Golden Verses. However, here too, the

\footnotetext{
92 Morrow \& Dillon 1987, pp. 101-102.

93 Westerink 1987b, pp. 110-111.
} 
philosophy of Empedocles is presented in a very similar, Pythagorean way:

According to the doctrine of Empedocles we have in us Love and Strife; through Strife we become dissolved and dissipated, and encounter pain, while through Love we are unified and meet with delight. By the agency of Love we are elevated, and by that of Strife we are made to sink, and our falling into evils of our own choosing occurs when we sink to the lower level, and our intellects enter the world of coming-to-be. (110b) ${ }^{94}$

As we can see, the connection between both texts - the two commentaries, Proclean and Arabic, is very strong. In both cases, Empedocles' idea of Love and Strife is used as a tool to comment on the Pythagorean theory of unity in its "psychological" aspect, applied to human beings and not in its cosmogonic, metaphysical aspect.

To conclude, the fact that the author of the commentary was convinced that Empedocles was the author of the Golden Verses, and that he closely connected Empedocles with the Pythagorean tradition, cannot be considered to stand in contradiction with the preserved works of Proclus. If it were, such a contradiction would indeed exclude Proclus Diadochus as the possible author of the commentary. On the contrary, there is nothing in the way in which the commentary describes Empedocles and his philosophy that would disagree with any

$94 \quad$ Linley 1984, p. 93. statement about those matters in Proclus' Greek writings.

\section{THE COMMENTARY AND THE LIFE OF PROCLUS BY MARINUS}

Since the core of the Golden Verses is devoted to practical ethics and the proper way of life, the Arabic commentary apart from some passages devoted to theology and metaphysics - also focuses mainly on ethical matters and on prescribing the perfect philosophical way of life. Therefore, it is very interesting to compare this text with another text from the circle of Proclus devoted to this subject: Proclus or On Happiness, known also as the Life of Proclus. This text was delivered as a speech in the form of a eulogy by his student and successor in the Academia, Marinus, one year after the death of Proclus. ${ }^{95}$

Marinus' idea was to show Proclus as a perfect example of human happiness and the incarnation of all sorts of virtues man can achieve. Marinus very often evokes his master's humility and the fact that he always considered himself as being a servant of the gods - as if he wanted to show that he never forgot the words that we read in the Arabic commentary:

We must seek divine aid to help us in our exertions, rather than act as those who say: "I do not need to pray or beseech, because I have already attained virtue". People who say this are misguided, since

95 For a more comprehensive discussion of this text, see the introduction to its edition and translation: Saffrey \& Segonds 2001, pp. IX-CLXXVI. 
whatever derives its existence and its virtue from a source that is other than itself, must cling everlastingly and unceasingly to that other source, and because all except God needs Him for its perfection, even though it may have attained the acme of virtue. $(108 a-b)^{96}$

Furthermore, Marinus (17) devoted an entire passage of his biography to show Proclus as a perfect friend, almost an incarnation of the Pythagorean model of friendship. He writes that although he did not have his own wife and children, he cared for his friends and their families as if they were his own. He was always present when someone did not feel well and tried to help as much as he could. He was also very kind and caring towards his servants. Among his many friendships, the one with Archiades, the grandson of Plutarch of Athens, was exceptional and Marinus described it as belonging to the special category of "Pythagorean friendship" (pythagoreion philia).${ }^{97}$ Strikingly, this is one of only three places in the entire Life of Proclus where Marinus directly evokes the Pythagorean tradition (the second is in chapter 15, where he evokes the Pythagorean saying "live unknown", while the third is in chapter 28, where he writes about Proclus' dream that he had a soul of the Pythagorean Nicomachus). "Pythagorean

96 Linley 1984, pp. 82-83.

97 About Archiades and his special role in the Proclean Academy as its "public voice" see: Watts 2006, pp. 107-108. friendship" 98 was certainly a well-known topos at that time. ${ }^{99}$ Iamblichus, who devoted two separate chapters of the Pythagorean Way of Life (XXII; XXXIII) to friendship, writes that it was actually Pythagoras who "discovered" the philosophical idea of friendship and that his followers were so perfect an example of it that the notion of the "Pythagorean friendship" had become proverbial in his times. ${ }^{100}$ Iamblichus concluded:

For they perpetually exhorted each other, not to divulse the God within them. Hence all the endeavour of their friendship, both in deeds and words, was directed to a certain divine mixture, to a union with divinity, and to a communion with intellect and a divine soul. (XXXIII, 240, trans. T. Taylor) ${ }^{101}$

The author of the commentary preserved in Arabic also devoted much of his text to the subject of friendship, as this topic occurs in verses 5-7 of the Golden Verses. ${ }^{102}$ He gives advice on how

98 Vogel 1966, pp.150-159; Saffrey \& Segonds 2001, pp. 124-125; Cornelli 2013, pp. 67-69.

99 See for example Damascius, 103.

100 "According to the general opinion it was Pythagoras who discovered it [i.e. friendship] and gave it legal form. He taught his followers a friendship so admirable that even today it is popularly said of people who are well disposed towards each other: they are Pythagoreans." (Iamblichus, Vita Pythag. XXXIII, 230, trans. C. J. Vogel) Vogel 1966, p. 151.

101 Taylor 1965, p. 123.

102 "Among others, choose as your friend him who excels in virtue.

Yield to his gentle words and useful actions,

And do not hate your friend for a small fault" (trans. Thom 1995, p. 95) 
one should look for a friend and how to care for friendship. Just like the late antique works on Pythagoreans, ${ }^{103}$ the commentator emphasises that for them friendship was even more important than kinship. As he explains, it was voluntary and based on the communion of values higher than that of blood, these being intellect, virtues and the unifying connection with God:

Friendship was venerated among the Pythagoreans, who regarded it as a symbol of union with the gods. $(95 a)^{104}$

Then, the commentator explains why friendship should be based on the virtues of the soul and not on physical beauty, wealth, possessions, power, etc. Once again he evokes the unifying aspect of the friendship, this time quoting Plato:

In his prayers, Plato used to ask and call upon God to make hearing, sight, and senses common to all. The saying "I have, or I do not have, a share" is meaningless within the context of friendship.

(...) And the more abundant is the virtue, the more stable will be the friendship, and anyone who exhibits a genuine ardour for virtue will be a staunch friend." (96a) ${ }^{105}$

Similarly, Proclus connects friendship with virtue and describes it as the

For example, Iamblichus, Vita Pythag. XXXV, 257.

104 Daiber 1988, pp. 24-25.

105 Linley 1984, pp. 26-29. unifying force in the Commentary on Alcibiades:

Let those who are at peace observe another, greater and more perfect good, viz. friendship and unity. This is the aim of virtue as a whole, so the Pythagoreans assert and also Aristotle, who rightly observed that "when all people are friends we have no need of justice" and "mine" and "thine" are annulled, but "when everyone is just we still have the need of friendship to unite us." (221.18-222.2; trans. W. O’Neill). ${ }^{106}$

Proclus evokes here Aristotle's Nicomachean Ethics, more precisely its chapter devoted to friendship and the saying: "when the citizens, indeed, are friends, there is no need of justice; but though they are just they require friendship," (1155a26-9, trans. T. Taylor). ${ }^{107}$

The author of the Arabic commentary also seems to be influenced strongly by Aristotle's ideas. We see that in his passages commenting on the question of friendship. It is visible not only in the fact that he makes connections between friendship, virtue and justice, but also in how he perceives the three types of virtues: "those belonging to the soul, those to the body and those that are external" (95b). He also says that the "choice of a friend should be made from the standpoint of his virtue of soul" - which altogether reflects Aristotle's division into

\footnotetext{
107 Taylor 2002, p. 370
}

INTERNATIONAL ISSUE N0.6/2019 I ANHP 
three kinds of good (Nic. Eth. 1098b 12-14). ${ }^{108}$

Furthermore, in the above quoted passage from the Commentary on Alcibiades, Proclus wrote that “'mine' and 'thine' are annulled" in friendship. The Arabic commentary reads: "II have, or I do not have, a share' is meaningless within the context of friendship." All these statements are very similar and point to the same source (if not the same author). They may be an echo of the famous Greek proverb "all things are common among friends" (koina ta ton philon) which is also quoted by Aristotle in the Nicomachean Ethics. This phrase appears in a chapter devoted to friendship, with a comment that it is right because "friendship consists in communion"109 (1159b, 31-32), and again in the same chapter, together with other proverbs on friendship, that is "[friends] are one soul" and "Friendship is equality" (1168a, 7-8). ${ }^{110}$ This classic Aristotelian locus seems to be reflected once again in the Arabic commentary, where the author writes that friendship "is sharing one's worldly possessions and placing one's friend on an equal footing with oneself" (96b, p. 29). This is also probably a reference to the question of alleged "communism" between the first Pythagoreans. Although koina ta ton philon is an old Greek proverb ${ }^{111}$

108 Cf. Westerink 1987a, pp. 64-65.

109 Taylor 2002, p. 381.

110 Taylor 2002, p. 402.

111 See for example: Euripides, Orestes 735; Plato, Phaedrus 279c 6; Leges 739c 2; Respublica V 449c; Aristotle, Ethica Eudemia 1238a 16; 1237b 33; Politica 1263a 30; Plutarch, De fraterno amore it was also connected with the legends of Pythagorean friendship and treated by some authors as directly referring to the community of property between the Pythagoreans. ${ }^{112}$ This shows that the author of the Arabic commentary was not only well educated in classical Greek paideia and was thinking within the framework of classical Greek philosophy, but he was also very well aware of all the Pythagorean legends and topoi circulating, especially in the Neoplatonic milieus of Late Antiquity.

Later on, the commentator offers an interesting explanation of the verses of the poem in which he recommends forgiveness for small errors when they are committed by a friend, but adds a warning that this forbearance has to end when there is something which "cause(s) alienation from God, and arouse(s) His anger" (97a). Therefore, his idea of Pythagorean friendship was basically the same as that of Iamblichus. They both underlined the same elements and both saw Pythagorean friendship as a way of becoming similar to One-God through unification of minds and souls among friends.

Proclus himself wrote about Pythagorean friendship several times. We read in his Commentary on Plato's Parmenides:

Again we learn that souls are perfected by friendship and worthy associations. This was the rule of the Pythagoreans especially, who made the most sincere

490e 4; Diog. Laert. IV, 53, 8-54, 1; VI, 37, 6; Clem. Alex., Protrepticus XII, 122, 3.

112 Minar 1944; Cornelli 2013, pp. 64-67. 
friendship the end of life for themselves. $(677)^{113}$

For the unity among the gods is not to be expressed in words and is hard for lesser beings to grasp; likewise the community of thought among good men escapes those not acquainted with them. Indeed the affection that unites them has a great affinity with the Pythagorean life (for the Pythagoreans made friendship the end of their life together and directed all their efforts to this end) and with the whole subject of this dialogue [Parmenides]. For unity and fellowship come to all things from the One, the inferior beings ever united with their superiors, being grouped together around their henads, and these around the One. (702) ${ }^{114}$

Proclus recalls the Pythagorean idea of friendship in some other commentaries as well, ${ }^{115}$ but it is in the Commentary on Parmenides that his understanding of this subject is presented in most detail. True friendship is a union of good men, which is analogous to the union of the gods-henads with the OneGod. ${ }^{116}$ As such, friendship is another

113 Morrow \& Dillon 1987, p. 60.

114 Morrow \& Dillon 1987, pp. 78-79.

115 "But one should also bear in mind that the dialogue is Pythagorean, and one should make one's interpretative comments in a manner that is appropriate to them. You could surely derive from it Pythagorean moral doctrines of the following kind: those gentlemen made friendship and the life of concord the target of all their philosophy." (I, 15,27-30) Tarrant 2006, p. 110.

116 About Proclus' theory of gods-henads as participating in the One-God see Chlup 2012, pp. 112-136. name for the process of unification that brings all hypostases and all particular beings back to the One. This is the idea shared by Proclus and Iamblichus, as well as our commentator, and probably also by Marinus, who shows Proclus as a perfect example of such a friendship. Moreover, the entire Arabic commentary shares a lot in common with the passage from Proclus' Commentary on Parmenides I just discussed. It is focused on the subject of the unity of man with God and on the theme of unity in general (for example, showing Empedoclean Love and Pythagorean friendship as important unifying forces). As such, it complements the other works of Proclus by showing the practical way to achieve this main goal of man and philosopher. ${ }^{117}$ Marinus, in turn, shows Proclus as someone who actually fulfilled this Pythagorean model with his own life.

These are not the only common places between Marinus' Life of Proclus, our Arabic commentary and Iamblichus' Pythagorean Life. Most of these similarities are related to the practical side of the philosophical way of life. For example, Marinus (24) writes that Proclus used to sleep as little as possible, considering sleep to be "laziness of the soul" and that he used to wake up a way before the sunrise. And thus, we read in the Arabic commentary:

They used not to countenance sleeping at sunrise, so that the giver of light and life

117 About Proclus' idea of unification of the human soul and the ways of obtaining it see Chlup 2012, pp. 163-184. 
should not rise while they were asleep. $(106 b)^{118}$

This alleged Pythagorean cult of the rising sun is also attested by Iamblichus:

Conformably likewise to the precepts of their master, the Pythagoreans always rose from bed before the rising of the sun; (...). They also carefully observed to adore the rising sun. (XXXV, 256; trans. T. Taylor) $)^{119}$

The cult of the sun-Helios as a god is very well attested among the late Neoplatonists, including Proclus. We have Proclus' Hymn to Helios, as well as emperor Julian's hymn or oration to King Helios. ${ }^{120}$ Proclus expresses his devotion to the sun as a god in several places of his preserved works. ${ }^{121}$ According to Saffrey and van den Berg, the strong interest of the Neoplatonists in the cult of the sun emerged both from the traditional Hellenic religious practice and from Platonic texts (in particular the comparison of the Good to the sun in Plato's Republic). ${ }^{122}$ Therefore, this is actually a description of a late antique Neoplatonic practice of waking up before the sunrise and praying to the rising sun, and it is a topos common to all three texts, which places the Arabic Taylor 1965, pp. 131-132.

See the translation of Proclus' Hymn to Helios with introduction and commentary in R. M. van den Berg 2001, pp. 145-189.

121 Saffrey 2000.

122 Saffrey 2000; Van Den Berg 2001, p. 146. commentary in the same literary tradition.

In the same context, the Golden Verses exhort to moderation in eating and drinking, as well as in everything that affects the body (verses 32-35). ${ }^{123}$ The author of the Arabic commentary explains how this moderation can be achieved. Food should always be moderated not only in terms of quantity, but also quality, and it should be as simple and pure as possible. He writes:

Pythagoras commands that we "reject the body", because to those who possess intelligence, a life of freedom from the body is sweeter than with it (...); one who rejects the life of the body is not readily envied but is rather praised (...). Good conduct is to be achieved through co-operating well with people, through moderation in dealings with them, good social comportment, courteous behaviour, grace of speech, and helpfulness towards others. $(105 a)^{124}$

123 "You should not be careless about your physical health,

But you should practice due measure in drinking, eating and physical exercises.

By due measure I mean that which will not distress you.

Become accustomed to have a pure way of life, not an enervated one." (32-35, trans. J. C. Thom, p. 97).

124 Linley 1984, pp. 66-69. The same motif is repeated later in the text $(112 a-b$, pp. 98-99): “The starting-point towards intellectual purity is the undertaking of practices such as will loosen the bonds attaching it to the body, and release it from its submission to the bestiality that is in it (...). We must not allow ourselves to be beguiled by variety or sweetness of foodstuffs, but should rely upon foods that are beneficial and those that are simplest and most delicate." 
This is very similar to the way in which Marinus described Proclus in his eulogy and Iamblichus described Pythagoras in the Pythagorean Way of Life. Obviously, it was a mere topos, but again it is shared by these three authors. Interestingly, all three authors considered vegetarianism to be part of this topos of a moderate life (Procl. Arab., pp. 66, 99; Marinus 12; 19; Iamblichus Vita Pythag. III; XXIV). Such a recommendation is not explicitly made in the Golden Verses, yet it had been connected with Pythagoreanism by late antique authors, starting with Porphyry, in his work devoted to vegetarianism (On Abstinence 2, 28). ${ }^{125}$ The Arabic commentary is very clear about that precept:

[Pythagoras] advises that food be simple and pure. Most foods that are easily digested by the eater come from inanimate sources, and those who believe that we ought to nourish ourselves on food that is animate, are being foolish. $(104 b-105 a)^{126}$

This is a very decisive voice in the late antique Neoplatonic debate on whether a man should or should not eat meat. The commentator uses the Golden Verses which do not address this question - as well as the very authority of Pythagoras to promote his own point of view. This actually tells us a lot about his philosophical "affiliation". We can certainly place him very close to Iamblichus as well as to Marinus, and probably also to Proclus. They all agreed on the righteousness of vegetarianism, and the author of the Arabic commentary and Iamblichus both connected it with the authority of Pythagoras.

Finally, the Life of Proclus and our commentary show surprising affinity in matters of religiosity. Throughout his eulogy, Marinus emphasises Proclus' devotion to various pagan deities and his care for all the details of the practice of their cult $(11 ; 19 ; 28-34)$. It goes along with the commentary, which addresses the question of the cult of goods, demons and heroes several times and gives some details concerning proper worship practices (92a-93a; 94a-b). At the same time, the commentary has a strongly monotheistic character and it is obvious that its author placed one God above the entire hierarchy of gods and semi-divine creatures. Also, Proclus himself strongly defends the monotheistic theology and monistic metaphysics against all dualist theories in his theology and in his theory of the cause of the evil. ${ }^{127}$

According to Marinus, Proclus' astonishing devotion to the cult encompassed even the worship of heroes and of dead ancestors and relatives:

Under no circumstances did he neglect to render the customary homages, and on fixed yearly dates he went to visit the tombs of the Attic heroes, those of philosophers, of his friends and acquaintances; he performed the rites prescribed by religion (...). After having fulfilled this pious duty towards each of them, he

127 Dodds 1992; Phillips 2007; Chlup 2012, pp. 201-233. 
went to the Academy, in a certain particular place, and by vows and prayers, he invoked the souls of his ancestors, collectively and separately; and (...) he made libations in honour of all those who had participated in philosophy. $\left(36\right.$, trans. K. S. Guthrie) ${ }^{128}$

Let us compare this passage with the Arabic commentary:

For these [the souls of the dead] the law prescribes celebration for one day per year; for the heroes, the regulation is for one day's celebration per month, while for the demons perpetual celebration is ordinated. $(94 a-b)^{129}$

Pythagoras held the heroes in esteem also, and we honour them by believing that they requite with evil or good whoever does harm or good to them. For them there are prescribed exaltation, incense and sacrifice on the twenty-fifth day of January.

Pythagoreans enjoined long journeys to visit the most virtuous dead, and to pray over their graves, and lay it down that God gives rewards for this and punishes those who do not do their duty.

(...) Pythagoras makes it a duty to honour good men (...) and to show affection to relatives, and to treat them with respect, since we have them through nature. We should honour them in a measure commensurate with their merits (...) We should give preferential treatment to our relatives as against those who are not related to us; we should also show

128 Guthrie 1986, p. 53.

129 Linley 1984, pp. 19-21. greater honour to certain individuals because of the virtue which has made them good, and make them partners in our lives. (94b-95a) $)^{130}$

Thus, the commentary presents the Pythagoreans as people who observed the prescription to worship the "most virtuous dead" and Pythagoras (and the Golden Verses) as the authority who recommended this practice; the commentary also gives the reason for undertaking these practices. Likewise, Marinus portrays Proclus as someone who with great care and piety obeys similar recommendations in every detail, in exactly the same way as the ancient Pythagoreans did. ${ }^{131}$

Until now, I have been focusing on the numerous similarities between the Arabic commentary and Marinus Life of Proclus, as well as the writings of Iamblichus. However, there is one point in the matters of religiosity on which our commentary and the eulogy of Proclus disagree: whereas, according to Marinus, Proclus worshipped Hellenic and foreign gods on equal terms, our commentary recommends worshipping only one's "native" deities.

Thus, Marinus emphasises that Proclus used to worship as many gods as possible and celebrated religious feasts and fasts, not only Hellenic but also foreign. According to him, Proclus wrote hymns not only to the Hellenic gods, but also to several foreign gods ("without

130 Linley 1984, pp. 20-23.

131 See also a commentary to this passage in: Fowden 2005, pp. 152-153; and Dillon 2007, 130-131. 
exception"), such as Marnas of Gaza, Asclepius Leontouchos of Ascalon, Thyandrites, who was worshipped by the Arabs, and Isis of Philae (Egypt). ${ }^{132} \mathrm{He}$ was doing it according to his statement that "it behoves the philosopher to be no minister of any one city, nor even of any particular people's customs, but to be a sacral hierophant of the entire world in common," $(19,47-48) .{ }^{133}$ Thus, in the image of Proclus drawn by Marinus, the actual religious practice is presented as extremely eclectic and embracing every possible cult from the entire oikumene and it is explained by Proclus' statement about the philosopher as the "hierophant of the entire world". However, this very statement does not seem to fit this context well, since it can be understood in a completely opposite way to how Marinus presented it in his eulogy. Garth Fowden, who commented on this passage by Marinus, referred to Porphyry's idea (De Abst. 2.49.1) that a philosopher as a priest "is responsible not merely for the statues of the gods, but for making himself into a statue". ${ }^{134}$ It was probably Porphyry's allusion to the anecdote of Plotinus described by Porphyry (Vita Plot. 10.35-6). Plotinus being asked about participating in a religious ceremony replied that "they ought to come to me, not I to them". ${ }^{135}$ Fowden quoted in this context Proclus

132 See the commentary to this passage and the information about those gods in Saffrey \& Segonds 2001, pp. 132-133 and Edwards 2000, pp. 87-88.

133 Translation by Luz 2017, p. 146.

134 Fowden 2005, p. 154.

135 About this anecdote and more about Plotinus' and Porphyry's approach to
(In Parm. 618) who described his teacher Syrianus in a very similar way, as someone who as a philosopher can "recompense for the statues, the temples and the whole ritual of worship" and that he himself was able to be "the chief author of salvation for men". ${ }^{136}$

Furthermore, thanks to the partially preserved Platonic Theology, as well as the Elements of Theology, we are very well informed about Proclus' theology and that he considered particular pagan gods as henads that were placed in his elaborated metaphysical hierarchy below the transcendent One (but at the same time somehow participating in it). In his Platonic Theology, Proclus managed to fit every single Olympic, Orphic and Chaldean (i.e., from the Chaldean Oracles) god, placing them on subsequent levels of the "Platonic" hierarchy of beings emanating from the One and at the same time being unified with it. ${ }^{137}$ It is possible, therefore, to read this sentence of Proclus' about him being a hierophant of the entire world as referring to this universal character of his philosophical theology, hidden beneath the traditional pagan mythology and religious practices. This would be the actual meaning of the traditional religion that only a philosopher can truly comprehend. ${ }^{138}$ Consequently, it

traditional religion see van den Berg 1999; and Chlup 2012, pp. 260-261

136 Fowden 2005, p. 154; Morrow \& Dillon 1987, p. 20.

137 Chlup 2012, pp. 112-136; Butler 2008.

138 This is how J.M. Dillon (2007, p. 133) understood Marinus' statement of Proclus as a hierophant of the entire world. According to him this statement was 
is possible that Marinus added this sentence, which he might have remembered as something that his master actually had said and he referred it to Proclus' religious practice. ${ }^{139}$ This hypothesis could be corroborated by the fact that Marinus was considered by others scholars from the circle of Proclus as lacking understanding of the intricacies of the Platonic philosophy which means basically metaphysics and theology. ${ }^{140}$ In this context, it is striking that those hymns of Proclus that survive until today are only devoted to the traditional Hellenic

connected with a concern of intellectuals like Proclus to "fit all local divinities into the system" it is to identify every local deity with one of the Hellenic gods. However, this syncretic approach described by Dillon is not consistent with Marinus' description of Proclus worshipping every single local deity possible (since there is no sense in committing to the cult of every one of them as they can be easily identified with Greek Olympic gods). M.J. Edwards, in turn, considered this statement to be "a variation on the notion that a philosopher should be a 'cosmopolitan' or citizen of the world, which is ascribed to Diogenes, founder of the Cynics". Edwards 2000, p. 88. Finally, R. Chlup (2012, pp. 264-265) understands this statement as an expression of "the burden of cultural responsibility the Neoplatonists were taking on their shoulders"; it is the responsibility of continuation of the traditional Hellenic cults (however, it does not really apply to the passage by Marinus in which he shows Proclus as devoted to cults of gods other than traditional Hellenic ones).

139 Van Den Berg 2001, pp. 29-30; Luz 2017, pp. 146-147. See more about Proclus' religious practice in Festugière 1966.

140 See. Damascius, Philosophical history / Life of Isidorus 97 (ed. Athanassiadi, pp. 237-239); Cf. Watts 2006, p. 113. gods. ${ }^{141}$ Therefore, there is no trace in Proclus' preserved writings, neither religious nor philosophical, that would attest that he actually worshipped any foreign minor deities like those mentioned by Marinus. It is possible that Marinus described Proclus as a worshipper of every possible god because he himself was a convert from a foreign cult, so he did not mean to describe honestly the actual religious practice of his teacher. There is also a possibility that this list of foreign gods allegedly worshipped by Proclus, as given by Marinus, reflects domestic cults of some students in the Athenian Academy under Proclus. It would suggest that Proclus showed a welcoming attitude to all of them and to their religious and cultural background - rather than his own actual religious practice. ${ }^{142}$

However, there is no doubt that religious practice was important for Proclus and that he considered himself a philosophical and religious leader, obliged to preserve and guard the elements of Hellenic traditional cult that were seriously threatened by Christians. ${ }^{143}$ The only question is how far his piety reached from the cult of the traditional Hellenic gods toward the gods of barbarian cities and nations, which is what Marinus claims about him.

141 Van Den Berg 2001; Saffrey \& Segonds 2001, pp. 131-132; Luz 2017, pp. 148-149.

142 I owe this remark to Peter Brown, whom I would also like to thank for his help and support in the process of writing this paper.

143 Fowden 2005, pp. 154-157; Chlup 2012, pp. 264-265; Dillon 2007. 
It is in this context that we could probably understand the recommendations made by the Arabic commentary. We read:

Doing good varies according to the doer and his station, and so for each different rank there are differences in sacrifices, incense, the use of pigs and wine, and festivals, and so on, and in this matter ancestral ruling is followed; this is what is meant by "law" [in the poem]. The reason why the rulings of the law differ is that they conform to the difference among the minds, beliefs and habitations of men: the law of the Athenians was to sacrifice the pig and to make offerings of diluted wine, whereas the Egyptians refuse to sacrifice pigs. These are principles which were derived from Hermes, who commanded man to abide by the laws of his fathers and ancestors, and to avoid alien practices. In accordance with the disposition of each nation of mankind and its ancestral rule, the usages established by the wise men regarding sacrifice, festivals and incense vary, and they trace back these principles to the gods. This is why, if any nation transgresses against its own custom, it perishes. $(92 a-b)^{144}$

According to this passage, religious laws and practices of worship were given to humans by gods and they were adapted to the character of every nation. This idea brings the author to the point of religious conservatism and the opinion that every nation has to keep

144 Linley 1984, p. 8-11. his own ancestral religious practices, and nobody should get involved in the religions of other nations.

This opinion stands in obvious contradiction to what Marinus presented in the Life of Proclus. However, according to Damascius, Marinus himself was probably originally a Samaritan from Neapolis in Palestine who later converted to Hellenism. ${ }^{145}$ According to Menahem Luz, this conversion "was severely reprimanded by other members of the Platonic school". ${ }^{146}$ This is not so clear, as this statement is based on a reconstructed passage from Damascius, probably mixed with other statements added by Photius to his description of Marinus. ${ }^{147}$ The critique of Marinus' conversion might well have been added by the Byzantine scholar. However, it is very probable that he really was a convert from the Samaritan to the Hellenic faith and that he did abandon his ancestors' religion. ${ }^{148}$ This would somehow explain why he tried to show Proclus as accepting all kinds of foreign religious practices. Furthermore, the surviving passages of Damascius Philosophical history / Life of Isidorus reveal that the

145 This information is preserved in Photius' excerpt from the Philosophical history / Life of Isidorus, 97 (ed. Athanassiadi, p. 237): "Marinus, the successor of Proclus, originated from Neapolis in Palestine, a city founded near the so-called Mount Argarizos [Gerizim] (...). Born a Samaritan, Marinus renounced their creed (...) and embraced Hellenism."

146 Luz 2017, p. 145.

147 See a study of this passage of Damascius about Marinus' origins in Hult 1993.

148 See also Hult 1993; Schissel von Fleschenberg 1930; Saffrey 2005. 
Athenian Academy at that time was not a homogenous community. There were different factions in the Platonic school after (or probably even before) the death of Proclus and there occurred disagreements about the succession in the school as well as philosophical and religious differences between scholars in this circle. Conservatism, as expressed by our commentator, would have been opposed to the eclecticism embodied in Marinus. Therefore, this difference in opinions could have originated in the philosophical and interpersonal controversies that were tearing apart the Athenian Academy in the late fifth century AD. ${ }^{149}$

In this context, it is striking that the question of the worship of foreign gods is the only point in which Marinus and the Arabic commentary disagree. The rest of Marinus eulogy shows several common elements with the Arabic commentary, as if Marinus had wanted to show Proclus as fulfilling the model of life that is described by the commentator.

In conclusion, the comparison between Marinus' Life of Proclus and the Arabic commentary shows a lot of striking similarities, common attitudes to many questions and the use of the same topoi and loci from the Neoplatonic Pythagorean tradition. Furthermore, there is also a number of similarities between those two texts and the works of Proclus himself as well as with Iamblichus'

149 For the Athenian Platonic Academy at the times of Proclus as the diadochus and the years after his death, see Watts 2006, pp. 100-128; and the introduction of P. Athanassiadi in Damascius 1999, on pp. 39-48.
Pythagorean Way of Life. Studying those three texts together - Iamblichus, Marinus, and the Arabic commentary is particularly interesting since they all present the same ideal of the perfect, happy, virtuous life of a philosopher. This is the ideal of the pagan holy man (theios aner), so important for the late antique Neoplatonic tradition and so closely connected with the Pythagorean tradition itself (as seen by the late Neoplatonists): Pythagoras was seen as the first and most important living example of this ideal. ${ }^{150}$ The three authors speak in unison, even though they adopt three different points of view:

1. Iamblichus, in On the Pythagorean Way of Life, presents a description of the life of the legendary figure of divine Pythagoras and of the community of his first students - who serve him as perfect examples of the way of life to be followed.

2. Marinus, in Proclus, or On Happiness, offers a eulogy of the recently deceased teacher who perfectly embodied this Pythagorean ideal of the pagan holy man.

3. The "Arabic" commentator describes the same model of the perfect way of life, but this time based on the Golden Verses, the poem considered to be a collection of the admonitions of Pythagoras, written down by his famous student Empedocles; the poem focuses exactly on what the proper philosophical way of life should be.

See Fowden 1982. 
There is no doubt that all three texts were written by Neoplatonic authors who shared a similar education, the same literary and philosophical erudition, as well as a common philosophical system through which they saw the world, man and history. The differences in their opinions on specific matters, such as the question of the worship of foreign gods could be explained by the context of their creation, and they actually help us see the Neoplatonic philosophers of Late Antiquity as real people, who combatted and disagreed with each other. It is clear that we should look into this inner circle of Proclus' students if we are to find the original author of the Arabic commentary.

\section{CONCLUSIONS}

As I tried to demonstrate in the first part of this paper, the hypothesis of Proclus Procleius as the author of the Arabic Commentary on the Golden Verses in Ibn al-Tayyib's abbreviated version is very problematic and difficult to defend. Conversely, there is a strong affinity between this text and the preserved works of Proclus as well as the eulogy of his student and successor Marinus.

The surviving works of Proclus leave no doubt that he held Pythagoras and the Pythagoreans in very high esteem and venerated them together just as much as he venerated Plato and the Orphic tradition. This is visible, for example, in his famous statement from the introduction to the Platonic Theology:

But we must show that each of these doctrines is in harmony with the first principles of Plato and with the secret revelations of the theologians. For all Greek theology derives from Orphic mystagogy, Pythagoras first learning from Aglaophemus the secrets concerning the gods, Plato after him receiving the complete science of the gods from Pythagorean and Orphic writings. (I 5, 25, 24-26, 9, trans. D. O'Meara $)^{151}$

Marinus in the Life of Proclus (28) recalled that Proclus had a dream that the soul of Pythagorean Nicomachus lived in him. In turn, in the entry devoted to Proclus Diadochus, the Souda (Pi 2473) lists a text entitled About the harmony of Orpheus, Pythagoras and Plato among the writings attributed to him. If it had indeed existed, it would have probably been related to the same idea as the one expressed in the passage from the Platonic Theology, according to which the Orphic, Pythagorean and Platonic traditions are basically one and the same tradition. Moreover, it is possible to identify numerous Pythagorean elements in his commentaries to Plato's dialogues. In particular, Proclus considered the Platonic Timaeus to be Pythagorean in its very essence, ${ }^{152}$ but he also made many references to the Pythagorean tradition while commenting on Plato's Parmenides and his other dialogues. As pointed out by Dominic O'Meara, Proclus continued the Iamblichean Pythagorean project, which is plainly visible in his commentaries, where he shows that Plato's entire

151 O'Meara 1989, p. 146.

152 See especially Comm. in Tim. I, III 8; cf. Baltzly 2016; O’Meara 1989, pp. 148-149. 
work was based on Pythagoras. ${ }^{153}$ O'Meara also expressed the opinion that from this point of view, the Arabic commentary attributed to Proclus actually "contains ideas characteristic of Iamblichus' Pythagoreanizing programme, which reappear in Syrianus and in Proclus. If then the precise authorship of the Arabic commentary cannot yet be determined with certainty, it can at least be seen as further evidence of the influence of Iamblichus' revival of Pythagoreanism." 154

However, among his preserved writings there is not a single one devoted specifically to Pythagoras and his doctrine. Neither did Proclus write any work similar to Porphyry's and Iamblichus' lives of Pythagoras. Nevertheless, his interest in Pythagoras should have been substantial, as was his knowledge about him and his philosophy (inasmuch as it was available to a late antique author). Furthermore, there are many parallels between the Arabic commentary and the preserved writings of Proclus. Even though Westerink did not consider this enough to attribute the authorship of this text to Proclus himself, these similarities certainly place this text somewhere in the same philosophical milieu.

When we add to that the parallels between the Arabic commentary and Marinus' Life of Proclus, this leads us to the hypothesis that the Arabic commentary was written in the circle of direct students of Proclus. The text reflects very well the intellectual and interpersonal climate of this community, the opinions shared by its members and their familiarity with Proclus and his legacy, as well as the discussions that must have occurred within this group.

Furthermore, it is very probable that Proclus used to give lectures about the Pythagorean tradition and the Golden Verses. He believed that this poem had its origins in the very first stages in the development of the tradition that he saw himself belonging to, and that it was connected with Pythagoras himself. Neoplatonic philosophers also shared the opinion that this was a perfect propaedeutic text, ideal for a general introduction to philosophy and there is no reason to think that Proclus' opinion about it was different. ${ }^{155}$ Therefore, he could have commented on it during some of his lectures and some of his students could have written these comments down in the form of notes. Later on, someone might have reviewed and presented them as a standalone commentary. This would explain the attribution of the commentary to Proclus and its affinity with his legacy on the one hand, and its relatively free form on the other (no lemmata consecutively commented). We know that some Neoplatonic commentaries were said to be "apo phones", that is notes from a lecture of someone else than the compiler of the actual text. Marcel Richard in his study of this kind of late antique literary works presents a number of Neoplatonic commentaries which are explicitly presented as "the

155 See Hierocl. Comm. Aur. carm. 122, 1-5 Hadot 1978, pp. 162-164; Hadot 2004, p. 96; Schibli 2002, pp. 17-18. 
oral teaching of ...”, which is one of the most popular uses of the formula apo phones (although not the only one). ${ }^{156}$

Among the preserved commentaries attributed to Proclus there is actually one which consists of notes taken by a student who attended one of Proclus' seminars; it is the Commentary on Plato's Cratylus. ${ }^{157}$ The form of this text is very similar to the Arabic commentary on the Golden Verses; it does not comment on every single passage of the text, it makes substantial digressions and it is not always clear how the commentary relates to the commented text. ${ }^{158}$ Both texts are attributed to Proclus, and both comment on classical texts. There is no reason to reject the hypothesis that the Arabic commentary was - just as the commentary on Cratylus - not written by Proclus himself, but nevertheless comes from him and was actually written down by one of his students.

We must remember that medieval Arabic authors had access to a different source base of Greek philosophical texts that we have today - and different, perhaps even more comprehensive, than their medieval Greek counterparts

156 Richard 1950; Praechter 1990, pp. 43-45; see also the introduction by D. Baltzly \& R. Tarrant in Tarrant 2006, pp. 13-14.

157 Van Den Berg 2008, pp. 94-95.

158 "[The Commentary on the Cratylus] appears to consist of a series of garbled notes. Even though they apparently follow the text of the Cratylus, it is by no means always clear how exactly they relate to the Cratylus or to each other. (...) The commentary thus consists of 'useful excerpts (chresimoi eclogai) from notes (scholia) taken by a student who attended Proclus' seminar on the Cratylus." Van Den Berg 2008, p. 94. (i.e. the Byzantines). Therefore, from the modern perspective, there is no reason not to treat the Graeco-Arabic tradition on a par with the Greek tradition that has survived until the present day. And whereas for obvious reasons every classicist is reluctant to announce the discovery of a lost work by Plato or Aristotle in Arabic, we should not give up on the idea that Arabic texts can improve our access to the ideas and heritage of the greatest philosophers of Classical Antiquity.

Therefore, I argue that the Arabic commentary on the Golden Verses attributed to Proclus should receive more attention than it has. First of all, it is a very good exposition of Neoplatonic ethics, and one that can supplement the Greek corpus of Proclus' works. Radek Chlup in his introduction to Proclus' philosophy begins the chapter about Proclus' ethics acknowledging that although "most of the abstract metaphysical principles" of his system "have a number of interesting ethical consequences", "most of the time Proclus pays comparatively little attention to them". ${ }^{159}$ Then he writes:

His chief aim is to analyse things on as general a level as possible, so that the theorems arrived at in this way might subsequently be applied to any particular field of enquiry. Unfortunately, these particular applications are something Proclus rarely finds sufficient time for. As a result, modern readers, who only have access to Proclus' thought through his texts, may easily miss the fact that Neoplatonic metaphysics was not only

Chlup 2012, p. 234. 
thought but lived and practised as well. ${ }^{160}$

The Arabic commentary to the Golden Verses ideally fills in this lacuna in our sources for Proclean ethics. It is also a perfect example of the idea to which Chlup refers, namely that in Proclus' system ethics are closely connected with metaphysics and theology. Therefore, this text - preserved in Arabic - provides a perfect example of exactly what Chlup assumed that Proclus "rarely finds sufficient time for". It is a description of Neoplatonic ethics as part of the entire coherent philosophical system emerging from metaphysics and theology. Even if Proclus found little time to describe this ethics in his core writings, he would have been explaining it to his students.

Furthermore, the Arabic commentary attributed to Proclus may also be a valuable source of knowledge about the Neoplatonic image of Pythagoras, his life and philosophy, as well as a fascinating description of a philosophical way of life that was believed to be "Pythagorean" in the inner circle of Proclus' students. As such, the Arabic text brings us a number of interesting elements that can supplement the surviving Greek works of Proclus and his students. This includes an extensive and very interesting description of the Pythagorean metaphysics of number, which gives us extraordinary insight into the so-called Neo-Pythagorean number theory and its connection with metaphysics and theology.
In general, the Arabic commentary is a very good example of the late antique version of Pythagoreanism which, whether we want it or not, constitutes so much of the modern source base for the reconstruction of any historical facts about Pythagoras and his followers, as well as his philosophical views. We may consider it all late, and full of legends and myths, but this is also the case with the biographies of Pythagoras written by Porphyry and Iamblichus. Both are still the main sources from which modern scholars try to draw information about the most archaic period in the history of Pythagorean tradition. Why not add this interesting Arabic text to this corpus, and use it to study late antique Neoplatonism in general and the circle of Proclus in particular? 
Athanassiadi, P., Frede, M. (1999). Pagan Monotheism in Late Antiquity. Oxford: Clarendon Press.

Baltzly, D. (2004). "The Virtues and 'Becoming like God': Alcinous to Proclus". Oxford Studies in Ancient Philosophy 26, pp. 297-321.

Baltzly, D. 2007. Proclus, Commentary on Plato's Timaeus; Book 3, Part 1: Proclus on the World's Body. Cambridge: Cambridge University Press.

Baltzly, D. 2016. "Transformations of Pythagorean Wisdom and Psychic Askesis in Proclus' Timaeus Commentary". In: A.-B. Renger and A. Stavru (eds.), Pythagorean Knowledge from the Ancient to the Modern World: Askesis - Religion - Science. Wiesbaden: Harrassowitz.

Bosworth, C. E. (ed.), (1970). Hudūd AlĀlam; "The Regions of the World": A Persian Geography, 372 A.H.-982 A.D. Translated by Vladimir Minorsky and V. V. Bartol'd. Second edition. London: Luzac.
Brockelmann, C. (1937-1942). Geschichte der arabischen Literatur. Supplementbande. Leiden: Brill.

Brockelmann, C. (1943-1949). Geschichte der arabischen Literatur, 2nd ed. Leiden: Brill.

Brooks, E. W. (1901). "Arabic Lists of the Byzantine Themes". The Journal of Hellenic Studies 21, pp. 67-77.

Burkert, W. (1972). Lore and Science in Ancient Pythagoreanism. Translated by Edwin L. Minar orig. ed. Nürnberg 1962. Cambridge, Mass.: Harvard University Press.

Butler, E. P. (2008). "The Intelligibile Gods in the Platonic Theology of Proclus" Methexis 21, pp. 207-29.

Chlup, R. (2012). Proclus: An Introduction. Cambridge: Cambridge University Press.

Cornelli, G. (2013). In Search of Pythagoreanism: Pythagoreanism as an Historiographical Category. Studia Praesocratica 4. Boston: De Gruyter. 
Daiber, H. (1988). “(Rec.) LINLEY, NEIL: Ibn at-Tayyib, Proclus' Commentary on the Pythagorean Verses". Islam 65, pp. 134-37.

Daiber, H. (1995). Neuplatonische Pythagorica in arabischem Gewande: der Kommentar des Iamblichus zu den Carmina aurea; ein verlorener griechischer Text in arabischer Überlieferung. Amsterdam: North-Holland.

Damascius (1999). The Philosophical History. P. Athanassiadi (ed.). Athens: Apamea Cultural Association.

Damascius (2008). Commentaire sur le Philèbe de Platon. G. Van Riel, C. Macé, and J. Follon (eds.). Paris: Les Belles Lettres.

Delatte, A. (1915). Études sur la littérature Pythagoricienne. Paris: E. Champion.

De Smet, D. (1998). Empedocles Arabus. Une lecture néoplatonicienne tardive. Bruxelles: KAWLSK.
Dickey, E. (2007). Ancient Greek scholarship. Oxford: Oxford University Press.

Dillon, J. M. (2007). "The Religion of the Last Hellenes". Rites et croyances dans les religions du monde romain. Vandoeuvres Genève: Fondation Hardt.

Dodds, E. R. (1992). Proclus, The Elements of Theology. 2nd ed. Oxford: Clarendon.

Edwards, M. J. (2000). Neoplatonic Saints: The Lives of Plotinus and Proclus by Their Students. Translated Texts for Historians 35. Liverpool: Liverpool University Press.

Endress, G. (1973). Proclus Arabus. Zwanzig Abschnitte sus der Institutio Theologica in Arabischer Übersetzung. Beirut-Wiesbaden: Steiner.

Endress, G. (2012). "Proclus de Lycie. Oeuvres transmises par la tradition arabe". In: R. Goulet (ed.), Dictionnaire des philosophes antiques. Paris: CNRS. 
Ferrari, C. (2006). Der Kategorienkommentarvon Abū l-Farağ 'Abdallāh ibn aț-Ṭayib. Leiden-Boston: Brill.

Faraggiana di Sarzana, Ch. (1987). "Le Commentaire à Hésiode et La Paideia Encyclopédique de Proclus". By J. Pépin and H. D. Saffrey Proclus Lecteur et Interprète des Anciens (Actes Du Colloque International Du CNRS Paris (2-4 Octobre 1985)). Paris: CNRS.

Faultless, J. (2010). "Ibn Al-Ṭayyib" By D. Thomas and A. Mallett Christian-Muslim Relations: A Bibliographical History, Vol. 2 (900-1050). Leiden and Boston: Brill.

Ferrari, C. (2006). Der Kategorienkommentar von Abū al-Fară̌ 'Abdallāh Ibn aț-Ṭ ayyib. Leiden and Boston: Brill.

Festugière, A. J. (1966). "Proclus et la religion traditionelle”. Mélanges d'archéologie et d'histoire offerts à A. Piganiol. Paris: S. E. V. P. E. N.
Fowden, G. (1982). “The Pagan Holy Man in Late Antique Society". Journal of Hellenic Studies 102, pp. 33-59.

Fowden, G. (2005). "Sages, Cities and Temples: Aspects of Late Antique Pythagorism". By A. Smith The Philosopher and Society in Late Antiquity. Essays in Honour of Peter Brown. Swansea: Classical Press of Wales.

Guthrie, K. S., trans. (1986). The Life of Proclus or Concerning Happiness by Marinus of Samaria. Grand Rapids, Michigan: Phanes Press.

Gyekye, K. (1975). Abū L-Faraj Ibn Al-Tayyib, Tafsīr Kitāb İsāghūjī li-Furfūriyūs. Beirut: Dār al-Mashriq.

Gyekye, K. (1979). Arabic Logic: Ibn Al-T ayyib's Commentary on Porphyry's "Eisagoge”. Albany: State University of New York Press.

Hadot, I. (1978). Le problème du néoplatonisme alexandrin: Hiéroclès et Simplicius. Paris: Études augustiniennes. 
Hadot, I. (2004). Studies on the Neoplatonist Hierocles. Philadelphia: American Philosophical Society.

Hellenkemper, H., Hild, F. (2004). Lykien und Pamphylien. Tabula Imperii Byzantini 8, Wien: Verlag der Österreichischen Akademie der Wissenschaften.

Horst, P. C. van der. (1932). Les Vers d'or pythagoriciens. Leiden: Brill.

Huffman, C. A. (1999). "The Pythagorean Tradition". In: A. A. Long (ed.), The Cambridge Companion to Early Greek Philosophy. Cambridge: Cambridge University Press.

Hult, K. (1993). "Marinus the Samaritan: A Study of Vit. Isid. Fr 141". Classica et Mediaevalia 43, pp. 163-175.

Ibn Hawqal, M. (1964). Configuration de la terre (Kitab surat al-Ard) (transl. by G. Wiet and J. H. Kramers), Collection UNESCO d'œuvres représentatives. Série arabe. Beyrouth: Commission internationale pour la traduction des chefs-d'œuvre.
Izdebska, A. (2011). "Pitagorejska metafizyka liczb w arabskim komentarzu Proklosa do Złotego Poematu". Przegląd Filozoficzny. Nowa Seria 77, pp. 187-199.

Izdebska, A. (2016). "Man, God and the Apotheosis of Man in Greek and Arabic Commentaries to the Pythagorean Golden Verses". International Journal of the Platonic Tradition 10, no. 1, pp. 40-64.

Ja'far, Q. ibn. (1889). Kitâb al-Harâj. M. J. de Goeje (ed.), Bibliotheca Geographorum Arabicorum 6. Leiden: Brill.

Kaldellis, A. (2005). "The Works and Days of Hesychios the Illoustrios of Miletos". Greek, Roman, and Byzantine Studies 45, pp. 381-403

Khurradādhbih (1889). Kitāb al-masālik wa-al-mamālik. M. J. de Goeje (ed.), Bibliotheca Geographorum Arabicorum 6. Leiden: Brill.

Kingsley, P. (1995). Ancient Philosophy, Mystery and Magic: Empedocles and Pythagorean Tradition. Oxford: Clarendon Press. 
Köhler, F. W. (ed.) (1974). Hieroclis in aureum Pythagoreorum carmen commentarius. Stuttgart: Teubner.

Linley, N., (ed.) (1984). Proclus' Commentary on the Pythagorean Golden Verses. Buffalo, N. Y.: Dept. of Classics, State University of New York at Buffalo.

Luna, C., Segonds, A.-P. (2012). "Proclus de Lycie”. In: R. Goulet (ed.), Dictionnaire des philosophes antiques. Paris: CNRS.

Luz, M. (2017). “Marinus' Abrahamic Notions of the Soul and One". In: D. Layne and D. D. Butorac (eds.), Proclus and His Legacy. Berlin: De Gruyter, pp. 145-158.

Minar, E. L. (1944). "Pythagorean Communism". Transactions and Proceedings of the American Philological Association 75, pp. 34-46.

Mitchell, S., Nuffelen, P. van. (2010). One God: Pagan Monotheism in the Roman Empire. Cambridge: Cambridge University Press.
Morrow, G. R., Dillon, J. M. (1987). Proclus' Commentary on Plato's Parmenides. Princeton: Princeton University Press.

Nuffelen, P. van. (2010). Monotheism Between Pagans and Christians in Late Antiquity. Leuven: Peeters.

O’Meara, D. J. (1989). Pythagoras Revived: Mathematics and Philosophy in Late Antiquity. Oxford: Clarendon Press.

Phillips, J. (2007). Order from Disorder: Proclus Doctrine of Evil and Its Roots in Ancient Platonism. Leiden-Boston: Brill.

Praechter, K. (1990). "Review of the Commentaria in Aristotelem Graeca”. In: R. Sorabji (ed.), Aristotle Transformed. London: Duckworth, pp. 1000-1031.

Primavesi, O. (2016). "Empedocles' Cosmic Cycle and the Pythagorean Tetractys". Rhizomata 4 (1). pp. 5-29.

Proclus. (2007). On Providence. C. Steel (ed.). London: Bloomsbury / Bristol Classical Press. 
Richard, M. (1950). "Apo Phones". Byzantion 20, pp. 191-222.

Robbins, F. E., D'Ooge, M. L., Karpinski, L. C. (1926). Nicomachus of Gerasa, Introduction to Arithmetic with Studies in Greek Arithmetic. New York: The Macmillan Company.

Rosan, L. J. (1949). The Philosophy of Proclus. New York: Cosmos.

Rosenthal, F. (1990). "The Symbolism of the Tabula Cebetis According to Abū L-Faraj Ibn Aț-Ṭayib”. Greek Philosophy in the Arab World. Aldershot: Variorum.

Saffrey, H. D. (2000). "La dévotion de Proclus au Soleil". Le Néoplatonisme après Plotin. Paris: Vrin.

Saffrey, H. D. (2005). "Marinus de Neapolis”. In: R. Goulet (ed.), Dictionnaire des philosophes antiques. Paris: CNRS.

Saffrey, H. D., Segonds, A.-P. (2001). Marinus, Proclus ou sur le Bonheur. Paris: Les Belles Lettres.
Saffrey, H. D., Westerink, L. G. (1968). Proclus, Théologie Platonicienne. Vol. I. Paris: Les Belles Lettres.

Schibli, H. S. (2002). Hierocles of Alexandria. Oxford: Oxford University Press.

Schissel von Fleschenberg, O. (1930). "Marinos 1”. Paulys Realenzyklopädie. Stuttgart: Metzler.

Tarrant, H. (2006). Proclus, Commentary on Plato's Timaeus; Book 1: Proclus on the Socratic State and Atlantis. Cambridge: Cambridge University Press.

Taylor, T., (trans.) (1965). Iamblichus' Life of Pythagoras: Or, Pythagoric Life. London: JMWatkins.

Taylor, T. (2002). The Rhetoric, Poetic and Nicomachean Ethics of Aristotle (Volume $I V$ of the Works of Aristotle). Frome, Somerset: Prometheus Trust.

Thesleff, H. (1961). An Introduction to the Pythagorean Writings of the Hellenistic Period. Åbo: Åbo Akad. 
Thesleff, H. (1965). The Pythagorean Texts of the Hellenistic Period. Åbo: Åbo Akad.

Thom, J. C. (1995). The Pythagorean Golden Verses: With Introduction and Commentary. Leiden: Brill.

Van Den Berg, R. M. (2001). Proclus' Hymns. Essays, Translations, Commentary. Leiden: Brill.

Van Den Berg, R. M. (2008). Proclus' Commentary on the Cratylus in Context. Ancient Theories of Language and Naming. Leiden- Boston: Brill.

Van Den Berg, R. M. (1999). "Plotinus' Attitude to Traditional Cult: A Note on Porphyry VP c. 10". Ancient Philosophy 19, pp. 345-360.

Van Den Berg, R. M. (2003). “'Becoming like God' According to Proclus' Interpretations of the Timaeus, the Eleusian Mysteries, and the Chaldean Oracles". In: R. W. Sharples, A. D. R. Sheppard (eds.), Ancient Approaches to Plato's Timaeus. London: Oxbow.
Vogel, C. J. (1966). Pythagoras and Early Pythagoreanism: An Interpretation of $\mathrm{Ne}$ glected Evidence on the Philosopher Pythagoras. Assen: Van Gorcum.

Wakelnig, E. (2013). A Philosophy Reader from the Circle of Miskawayh: Text, Translation and Commentary. Cambridge: Cambridge University Press.

Watts, E. J. (2006). City and School in Late Antique Athens and Alexandria. The Transformation of the Classical Heritage 41. Berkeley: University of California Press.

Westerink, L. G. (1987a). "Proclus commentateur des Vers d'or". In: G. Boss, G. Seel (eds.), Proclus et son influence. Actes du colloque de Neuchâtel, Juin 1985. Zürich: Éditions du Grand Midi.

Westerink, L. G. (1987b). "Proclus et les Présocratiques". By J. Pépin and H. D. Saffrey, Proclus lecteur et interprète des Anciens (Actes du colloque international $d u$ CNRS Paris (2-4 Octobre 1985)). Paris: CNRS. 
Westerink, L. G. (ed.). (2010). Damascius Lectures on the Philebus. Westbury: Wiltshire.

Westerink, L. G. (2011). Proclus: Commentary on the First Alcibiades. L. G. Westerink (ed.), W. O'Neill (trans.). Westbury, Wiltshire, UK: Prometheus Trust.

Wilson N.G. (1983). Scholars of Byzantium. Baltimore: Johns Hopkins University Press.

Zampaki, T. (2017). "Ibn Al-Ṭayyib's Istithmār on Proclus' Commentary on the Pythagorean Golden Verses". By D. Layne and D. D. Butorac Proclus and His Legacy. Berlin: de Gruyter. 